\title{
Data report: permeability and consolidation behavior of sediments from the northern Japan Trench subduction zone, IODP Site C0019'
}

\author{
Robert D. Valdez II, ${ }^{2}$ Rachel M. Lauer, ${ }^{3}$ Matt J. Ikari, ${ }^{4}$ Hiroko Kitajima, ${ }^{5}$ and Demian M. Saffer ${ }^{2}$
}

\section{Chapter contents}

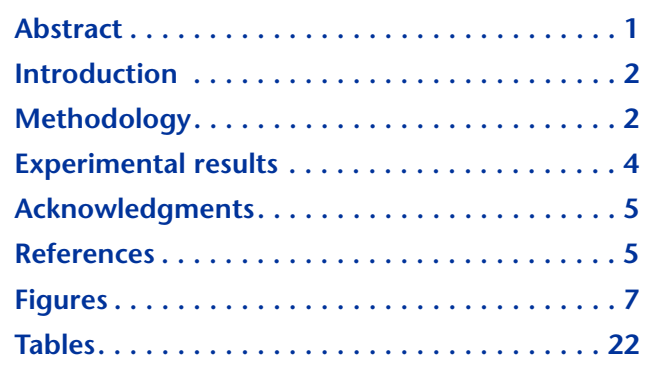

${ }^{1}$ Valdez, R.D., II, Lauer, R.M., Ikari, M.J., Kitajima, H., and Saffer, D.M., 2015. Data report: permeability and consolidation behavior of sediments from the northern Japan Trench subduction zone, IODP Site C0019. In Chester, F.M., Mori, J., Eguchi, N., Toczko, S., and the Expedition 343/343T Scientists, Proc. IODP, 343/ 343T: Tokyo (Integrated Ocean Drilling Program Management International, Inc.). doi:10.2204/iodp.proc.343343T.201.2015 ${ }^{2}$ Department of Geosciences and Energy Institute Center for Geomechanics, Geofluids, and Geohazards, The Pennsylvania State University, University Park PA 16802, USA.

Correspondence author: rdv116@psu.edu ${ }^{3}$ Earth and Planetary Sciences, University of California Santa Cruz, Santa Cruz CA, USA. ${ }^{4}$ Center of Marine Environmental Science, Universitat Bremen, Bremen, Germany. ${ }^{5}$ Department of Geology and Geophysics, Texas A\&M University, College Station TX, USA.

\section{Abstract}

Sediment hydraulic properties and consolidation behavior are key parameters that affect pore pressure generation, fluid migration, deformation, and slip behavior and mechanical strength of subduction zone megathrusts. We report on a set of constant rate of strain consolidation experiments and isostatic deformation and permeability experiments on whole-round core samples obtained during Integrated Ocean Drilling Program (IODP) Expedition 343 as part of the Japan Trench Fast Drilling Project (JFAST). The samples were collected from the frontal prism at 697.18 meters below seafloor (mbsf) and the underthrust sediment section at 831.45 mbsf at IODP Site C0019, $6.0 \mathrm{~km}$ landward of the Japan Trench. The permeability of sediment from the frontal prism decreases from $7.3 \times 10^{-18}$ to $3.5 \times 10^{-19} \mathrm{~m}^{2}$ as effective mean stress increases from 14.6 to $62.3 \mathrm{MPa}$ under a uniaxial loading path and from 5.4 $\times 10^{-18}$ to $2.9 \times 10^{-19} \mathrm{~m}^{2}$ over effective stresses from 3.6 to 54.6 $\mathrm{MPa}$ under an isostatic loading path. Porosity decreases from $46 \%$ to $27 \%$ as effective mean stress increases from 0.73 to $62.3 \mathrm{MPa}$ and $46 \%$ to $29 \%$ as stress increases from 3.6 to $64.6 \mathrm{MPa}$ for uniaxial and isostatic loading of the prism sediment, respectively. Permeability of the underthrust sediment sample decreases from $4.0 \times 10^{-18}$ to $3.2 \times 10^{-19} \mathrm{~m}^{2}$ as stress increases from 3.6 to 86.6 MPa under isostatic conditions. Porosity decreases from $49 \%$ to $37 \%$ over the stress range from 0.73 to $69.6 \mathrm{MPa}$ and $48 \%$ to $36 \%$ from 3.6 to $86.6 \mathrm{MPa}$ for uniaxial and isostatic loading paths, respectively. For both samples, permeability exhibits a log-linear decrease with decreasing porosity. In situ permeability for the prism and underthrust sediment samples are estimated from our laboratory-defined permeability-porosity relationships. The in situ porosity values for the prism sediment samples are $44 \%$ and $45 \%$ for uniaxial and isostatic conditions, respectively. The corresponding in situ permeability values are $4.3 \times 10^{-18}$ and $4.9 \times 10^{-18} \mathrm{~m}^{2}$. In situ porosity for the underthrust sample is $47 \%$ under both uniaxial and isostatic conditions. The permeability value for the underthrust sediment sample is $4.9 \times 10^{-18} \mathrm{~m}^{2}$ under isostatic loading conditions. The coefficient of consolidation $\left(C_{\mathrm{v}}\right)$ decreases with increasing effective axial stress to near-constant values of $4.2 \times$ $10^{-7}$ and $9.0 \times 10^{-6} \mathrm{~m}^{2} / \mathrm{s}$, and the compression index $\left(C_{\mathrm{c}}\right)$ is 0.70 and 0.57 for the prism and underthrust sediment samples, respectively. Preconsolidation stresses $\left(P_{c}^{\prime}\right)$ for the prism and underthrust samples, defined using the Casagrande method, are 17.0 
and 20.5 MPa, respectively, and correspond to overconsolidation ratios of 3.1 and 2.8.

\section{Introduction}

The 2011 Tohoku-Oki earthquake $\left(\mathrm{M}_{\mathrm{w}}\right.$ 9.0) and accompanying tsunami were caused by an extraordinarily large coseismic slip $(>50 \mathrm{~m})$ on the shallow portion of the subduction zone interface near the Japan Trench (Fujiwara et al., 2011; Ito et al., 2011). A rapid-response drilling operation by the Integrated Ocean Drilling Program (IODP), called the Japan Trench Fast Drilling Project (JFAST) (Expedition 343), drilled through the accretionary prism at IODP Site C0019 to investigate the physical mechanisms and dynamics that enabled the large shallow slip. Site C0019 is located $\sim 93 \mathrm{~km}$ seaward from the epicenter of the main shock and $\sim 6 \mathrm{~km}$ landward of the Japan Trench (Fig. F1) (Expedition 343/343T Scientists, 2013). Five boreholes were drilled at Site C0019 (Holes C0019A-C0019E), with logging while drilling (LWD) completed in Hole C0019B and coring intervals completed in Hole C0019E. Core samples of the frontal prism and underthrust sediment section were successfully recovered to 844.5 meters below seafloor (mbsf) (Expedition 343/343T Scientists, 2013).

We report on laboratory constant rate of strain (CRS) consolidation and triaxial permeability tests conducted on two whole-round core samples: 343C0019E-5R-1 (697.18 mbsf), a gray mudstone from Unit III in the frontal prism, and 343-C0019E-20R-1 (831.45 mbsf), a brown mudstone from Unit $\mathrm{V}$ in the underthrust section. These tests were designed to characterize the permeability and consolidation behavior under uniaxial and isostatic loading paths over a range of effective stresses. Results of these experiments are then used to estimate in situ hydraulic and mechanical properties of the sediment. This is directly related to the scientific goals of JFAST and will aid in the investigation of the physical controls on large shallow earthquake slip by providing constraints for future numerical models. All notations for this report are summarized in Table T1; core samples and their associated experiment numbers are summarized in Table T2. Experimental data for each uniaxial CRS and triaxial permeability test is provided in Tables T3 and T4 and in TESTDATA in "Supplementary material."

\section{Methodology}

At The Pennsylvania State University (PSU), wholeround core samples are kept in sealed aluminum vac- uum bags with wet sponges to minimize desiccation and stored in a refrigerator until subsampling and trimming. Once subsampling was complete, the remaining material was resealed in plastic core liners using plastic caps and electrical tape. During sample preparation, samples of whole-round Sections 343C0019E-5R-1 and 343-C0019E-20R-1 were trimmed to form cylinders $25.4 \mathrm{~mm}$ in diameter, with lengths ranging from 15.7 to $28.3 \mathrm{~mm}$, using fine point carving tools. These samples were aligned parallel to the whole-round core axis and collected from the same interval in each core, $697.18 \mathrm{mbsf}$ for the prism sample (Section 5R-1) and 831.45 mbsf for the underthrust sample (Section 20R-1). All uniaxial experiments were conducted at room temperature conditions $\left(24.0^{\circ} \mathrm{C}\right.$ ) in an oedometer system (Fig. F2). The triaxial experiments were conducted in a triaxial apparatus and maintained at a constant temperature of $29.5^{\circ} \mathrm{C}$ using a temperature chamber that surrounds the apparatus (Fig. F3). Syringe pumps controlled the pore pressure for all experiments, and deionized water was used to fill the pore fluid lines. A syringe pump also controlled both the confining and axial stress in the triaxial experiments, and silicone oil was used as the confining medium.

\section{Uniaxial constant rate of strain tests}

We conducted two uniaxial CRS tests in the Rock and Sediment Mechanics Laboratory at PSU. In the uniaxial CRS tests, the sample was placed within a steel ring and positioned in an oedometer system capable of reaching $50 \mathrm{kN}$ axial load (Fig. F2). Each sample was equilibrated for $24 \mathrm{~h}$ at $300 \mathrm{kPa}$ backpressure to ensure fluid saturation and that any air present in the pore pressure lines was completely dissolved. After backpressuring, a progressively increasing axial load was applied to the sample by specifying a constant displacement rate of $3.3 \times 10^{-5}$ to $5.0 \times$ $10^{-5} \mathrm{~mm} / \mathrm{s}$ using a computer-controlled load frame. In this configuration, pore pressure at the top of the sample is kept at a constant $300 \mathrm{kPa}$ during the consolidation stage. The base of the sample was undrained, and basal pore pressure was monitored throughout consolidation (ASTM International, 2006). Axial displacement and axial load were measured externally, and the measured displacement was corrected to account for the compliance of the oedometer system. Total axial stress $\left(\sigma_{\mathrm{A}}\right)$, basal pore fluid pressure $\left(P_{\mathrm{f}}\right)$, backpressure, and axial displacement were recorded every $10 \mathrm{~s}$ throughout the experiment.

Differential fluid pressure across the sample length during continuous loading induced fluid flow through the sample, and thus, the hydraulic conduc- 
tivity and permeability of the sample could be determined from the known strain rate $(\dot{\varepsilon})$ and excess basal pore pressure $(\Delta u)$, which is defined as the difference between the measured basal pore pressure and the backpressure (ASTM International, 2006; Long et al., 2008). Because the increase in basal pore pressure during loading depended on the rate of displacement, sample length, and hydraulic conductivity of the sample, we chose an appropriate constant displacement rate (or strain rate) for each sample such that $\Delta u$ was sufficiently large to be measurable with minimal error but remained $<12 \%$ of the effective vertical stress (e.g., ASTM International, 2006). Hydraulic conductivity $(K)$ is given by

$$
K=\left(\dot{\varepsilon} H_{\mathrm{n}} H_{0} \rho_{\mathrm{w}} \mathrm{g}\right) / 2 \Delta u,
$$

where

$$
\begin{aligned}
& \dot{\varepsilon}=\text { strain rate } \\
& \rho_{\mathrm{w}}=\text { density of water, } \\
& \mathrm{g}=\text { gravitational acceleration, } \\
& H_{\mathrm{n}}=\text { sample height at the time of interest, } \\
& H_{0}=\text { initial sample height, and } \\
& \Delta u=\text { excess basal pore pressure. }
\end{aligned}
$$

Permeability $(k)$ is then given by

$$
k=(K \mu) /\left(\rho_{\mathrm{w}} \mathrm{g}\right),
$$

where $\mu$ is the fluid viscosity at room temperature (0.001 Pa.s).

To allow for direct comparison of both the uniaxial CRS and triaxial tests, the effective mean stress $\left(\sigma_{\mathrm{m}}{ }^{\prime}\right)$ is reported for all of our experiments. To estimate the effective mean stress for the uniaxial CRS tests, in which a zero lateral strain boundary condition was imposed but lateral stresses were not measured, the coefficient of the horizontal stress at rest (denoted as $K_{0}$ ) is used; $K_{0}$ represents the ratio of horizontal to axial effective stresses. We assume a value of $K_{0}=0.6$, which is typical for clay-rich sediment (Karig, 1990). The effective mean stress $\left(\sigma_{\mathrm{m}}{ }^{\prime}\right)$ is then calculated as follows:

$$
\sigma_{\mathrm{m}}{ }^{\prime}=\left(\sigma_{1}{ }^{\prime}+\sigma_{2}{ }^{\prime}+\sigma_{3}{ }^{\prime}\right) / 3
$$

where $\sigma_{1}{ }^{\prime}, \sigma_{2}{ }^{\prime}$, and $\sigma_{3}{ }^{\prime}$ are the effective principal stresses.

In the CRS tests, the effective principal stresses $\sigma_{2}{ }^{\prime}$ and $\sigma_{3}{ }^{\prime}$ were equal (Fig. F2), and Equation 3 becomes

$$
\sigma_{m}^{\prime}=\left(\sigma_{A}^{\prime}+2 \sigma_{H}{ }^{\prime}\right) / 3 \text {, }
$$

where $\sigma_{A}^{\prime}$ and $\sigma_{H}{ }^{\prime}$ are the effective axial stress and effective horizontal stress, respectively. Given that $K_{0}=$ $\sigma_{H}{ }^{\prime} / \sigma_{A}^{\prime}=0.6$,

$$
\sigma_{\mathrm{m}}{ }^{\prime}=0.73 \sigma_{\mathrm{A}}^{\prime} .
$$

Using the hydraulic conductivity and the coefficient of volume compressibility $\left(m_{\mathrm{v}}\right)$ of the specimen, the coefficient of consolidation $\left(C_{\mathrm{v}}\right)$ can be calculated as follows (ASTM International, 2006):

$$
m_{\mathrm{v}}=\Delta \varepsilon / \Delta \sigma_{\mathrm{A}}^{\prime},
$$

and

$$
C_{\mathrm{v}}=K /\left(m_{\mathrm{v}} \rho_{\mathrm{w}} \mathrm{g}\right),
$$

where $\Delta \varepsilon$ and $\Delta \sigma^{\prime}$ are the changes in axial strain and effective axial stress. Specimen void ratio $(e)$ is calculated from the measured displacement (ASTM International, 2006):

$$
e=\left(H_{\mathrm{n}}-H_{\mathrm{s}}\right) / H_{\mathrm{s}},
$$

where $H_{\mathrm{n}}$ is the specimen height at a given point in the test, and $H_{s}$ is the equivalent height of the solids, which remains constant throughout the experiment. We determined $H_{s}$ for each sample from the wet mass and dry mass after oven drying at $105^{\circ} \mathrm{C}$ for $24 \mathrm{~h}$. Porosity $(\phi)$ is related to void ratio by

$$
\phi=e /(1+e) .
$$

A salt mass correction for the pore fluid was done following the IODP method used for moisture and density (MAD) measurements that accounts for salt in seawater (Blum, 1997). For our uniaxial tests, we also report the compression index $\left(C_{\mathrm{c}}\right)$, which is the slope of the virgin compression line in e-log $\sigma_{A}^{\prime}$ space (Table T3; e.g., Fig. F4):

$$
C_{\mathrm{c}}=\Delta e / \Delta \log \left(\sigma_{\mathrm{A}}^{\prime}\right) .
$$

The preconsolidation stress $\left(P_{c}^{\prime}\right)$ for each sample represents the maximum past burial stress in a monotonically increasing stress regime (Holtz and Kovacs, 1981). The preconsolidation stress is determined using two commonly used methods: the Casagrande and strain energy density (SED) methods. The Casagrande method defines $P_{c}^{\prime}$ graphically from the intersection of the virgin compression line and the bisector of a tangent and constant void ratio line from the point of maximum curvature in e- $\log \sigma_{A}^{\prime}$ space (Fig. F4) (Casagrande 1936). The SED method defines 
$P_{c}{ }^{\prime}$ using the change in the rate of total work as a function of effective axial stress (Becker et al., 1987). In the case of 1-D consolidation, SED is given by (Becker et al., 1987; Germaine and Germaine, 2009)

$$
\operatorname{SED}=\int \sigma_{A}^{\prime} \Delta \varepsilon
$$

Preconsolidation stress for the SED method was highly sensitive to the portion of the virgin compression line used to define a linear fit, resulting in large uncertainties. Therefore, the Casagrande values are used for determining the degree of consolidation. The overconsolidation ratio (OCR) for each sample is defined as

$$
\mathrm{OCR}=P_{\mathrm{c}}{ }^{\prime} / \sigma_{\mathrm{vh}}{ }^{\prime},
$$

where $\sigma_{\mathrm{vh}}{ }^{\prime}$ is the expected in situ effective vertical stress for hydrostatic conditions.

Effective vertical stress is calculated using the shipboard bulk density data (Expedition 343/343T Scientists, 2013). An OCR value $<1$ indicates that the sample is underconsolidated and that in situ pore pressures may exceed hydrostatic conditions, an OCR value of 1 indicates that the sample is normally consolidated, and an OCR value $>1$ indicates that the sample is overconsolidated.

\section{Isostatic loading and permeability tests}

A second set of deformation and permeability experiments were conducted in parallel with the uniaxial CRS tests to produce independent values of porosity and permeability under an isostatic stress path $\left(\sigma_{1}{ }^{\prime}=\right.$ $\sigma_{2}{ }^{\prime}=\sigma_{3}{ }^{\prime}=P_{\mathrm{c}}, P_{\mathrm{c}}=$ confining pressure), as opposed to the uniaxial stress path achieved in the uniaxial apparatus. For these tests, the sample was placed within a rubber jacket and loaded in a triaxial apparatus (Fig. F3). The sample was equilibrated for $24 \mathrm{~h}$ at $400 \mathrm{kPa}$ pore pressure to ensure saturation and that any air in the pore pressure lines was dissolved. After saturation and equilibration, specimens were loaded under drained isostatic stress conditions. The pore pressure was maintained at a constant $400 \mathrm{kPa}$, and the confining pressure and axial stress $\left(P_{\mathrm{c}}=\sigma_{\mathrm{A}}\right)$ was increased in a series of 8-10 stress steps, from 4 to $55 \mathrm{MPa}$ for the prism sample (Section 343-C0019E5R-1) and from 4 to $87 \mathrm{MPa}$ for underthrust sample (Section 20R-1) (see TESTDATA in "Supplementary material"). After each stress increment, we allowed the sample to equilibrate for $\geq 24 \mathrm{~h}$ prior to measuring permeability. Confining pressure and total axial stress, pore fluid pressure $\left(P_{\mathrm{f}}\right)$ of the upstream and downstream sample ends $\left(P_{\mathrm{p}_{\text {_up }}}\right.$ and $\left.P_{\mathrm{p}_{\text {_down }}}\right)$, axial displacement, and pore volume changes are recorded every $10 \mathrm{~s}$ throughout the experiment. Specimen po- rosity throughout the experiment is calculated based on final specimen porosity determined from wet and dry mass and from changes in pore volume recorded continuously during the test.

To allow for direct comparison of the triaxial tests with the uniaxial CRS tests, the effective mean stress $\left(\sigma_{m}{ }^{\prime}\right)$ is reported for all of our experiments. The effective mean stress $\left(\sigma_{m}{ }^{\prime}\right)$ for the triaxial experiments is defined as $\sigma_{\mathrm{m}}{ }^{\prime}=P_{\mathrm{c}}-P_{\mathrm{f}}$. Permeability was measured at each load step using a steady-state constant head method. In these tests, pore pressure gradients from 100 to $600 \mathrm{kPa}$ were imposed on the samples, and volumetric flow rates $(Q)$ were measured after reaching steady-state, defined using the criterion that the difference between upstream and downstream flow rates was $<5 \%$. Permeability was then calculated using Darcy's law:

$$
k=(Q \mu / A)\left[H_{\mathrm{n}} /\left(P_{\mathrm{p} \_ \text {up }}-P_{\mathrm{p} \_ \text {down }}\right)\right],
$$

where $A$ is the cross-sectional area of the sample and the pore pressure at the upstream, and downstream sample ends are $P_{\mathrm{p}_{-} \text {up }}$ and $P_{\mathrm{p}_{\_} \text {down }}$, respectively.

\section{Experimental results}

\section{Uniaxial CRS results}

Results from each CRS experiment are shown in Figures F5, F6, F7, F8, F9, and F10; Tables T3 and T4; and TESTDATA in "Supplementary material." Both permeability and porosity decrease with increasing effective axial and mean stress $\left(\sigma_{A}^{\prime}\right.$ and $\left.\sigma_{m}{ }^{\prime}\right)$, and permeability decreases log-linearly as a function of porosity below $37 \%$ porosity. Permeability of the prism sample (Section 343-C0019E-5R-1) decreases from $7.3 \times 10^{-18} \mathrm{~m}^{2}$ at $20 \mathrm{MPa}$ effective axial stress $\left(\sigma_{\mathrm{m}}{ }^{\prime}=\right.$ $14.6 \mathrm{MPa}$ assuming $K_{0}=0.6$ ) to $3.5 \times 10^{-19} \mathrm{~m}^{2}$ at 85 $\mathrm{MPa}\left(\sigma_{\mathrm{m}}{ }^{\prime}=62.3 \mathrm{MPa}\right)$, and porosity decreases from $46 \%$ at $1 \mathrm{MPa}\left(\sigma_{\mathrm{m}}{ }^{\prime}=0.73 \mathrm{MPa}\right)$ to $27 \%$ at $85 \mathrm{MPa}\left(\sigma_{\mathrm{m}}{ }^{\prime}\right.$ $=62.3 \mathrm{MPa}$ ). The underthrust sample (Section 20R-1) did not achieve a sufficient pore pressure gradient to determine the permeability (Fig. F8). Porosity decreased from $49 \%$ at $1 \mathrm{MPa}\left(\sigma_{\mathrm{m}}{ }^{\prime}=0.73 \mathrm{MPa}\right)$ to $37 \%$ at $95 \mathrm{MPa}\left(\sigma_{\mathrm{m}}{ }^{\prime}=69.6 \mathrm{MPa}\right)$ (Fig. F9).

Using the relationship between effective stress and porosity for each sample, as shown in Figures F8 and F11, we estimated in situ porosity ( $\phi_{\text {in situ }}$ ) based on an in situ effective vertical stress of $5.51 \mathrm{MPa}\left(\sigma_{\mathrm{m}}{ }^{\prime}=4.04\right.$ $\mathrm{MPa}$ ) for the prism sample (Section 343-C0019E-5R1) and $7.31 \mathrm{MPa}\left(\sigma_{\mathrm{m}}{ }^{\prime}=5.36 \mathrm{MPa}\right)$ for the underthrust sediment sample (Section 20R-1) (Table T4). In situ effective vertical stresses were calculated under the assumption of hydrostatic pore pressure. Estimated 
in situ porosity values are in agreement with the lower range of porosity values reported from shipboard measurements, $44 \%$ and $47 \%$ for the prism and underthrust samples, respectively. Shipboard porosities exhibit considerable scatter (from 40\%-68\%) and may be overestimated because the measurements include the effects of elastic rebound. This makes direct comparison between laboratory and shipboard measurements difficult.

Using the permeability-porosity relationship for the prism sample (Fig. F7), we estimated in situ permeability ( $\left.k_{\text {in situ }}\right)$ from the in situ porosity values (e.g., Dugan and Daigle, 2011; Guo et al., 2011). Estimated in situ permeability for the prism sample is $4.3 \times$ $10^{-18} \mathrm{~m}^{2}$ and corresponds to an in situ hydraulic conductivity $\left(K_{\text {in situ }}\right)$ of $2.7 \times 10^{-11} \mathrm{~m} / \mathrm{s}$ (Table T4). In situ hydraulic conductivity is estimated using a fluid viscosity based on the in situ temperature $\left(\sim 4^{\circ} \mathrm{C}\right)$ measured in Hole C0019E (Expedition 343/343T Scientists, 2013).

The coefficient of consolidation $\left(C_{v}\right)$ decreases with increasing effective axial stress to a constant value of $4.2 \times 10^{-7} \mathrm{~m}^{2} / \mathrm{s}$ and $9.0 \times 10^{-6} \mathrm{~m}^{2} / \mathrm{s}$ for the prism and underthrust sediment samples, respectively (Figs. F6, F9). The compression index $\left(C_{\mathrm{c}}\right)$ is 0.70 and 0.57 for the prism and underthrust sediment samples, respectively (Table T3). Preconsolidation stress and OCR for both samples indicate significant overconsolidation. $P_{\mathrm{c}}^{\prime}$ values for the prism and underthrust samples are 17.0 and $20.5 \mathrm{MPa}$ (Fig. F4), respectively, corresponding to OCR values of 3.1 for the prism sample and 2.8 for the underthrust sample (Table T3).

\section{Isostatic loading path results}

As in the uniaxial tests, both porosity and permeability decrease with increasing effective mean stress, and permeability decreases with decreasing porosity (Figs. F12, F13, F14; see also TESTDATA in "Supplementary material"). Permeability of the prism sample (Section 343-C0019E-5R-1) decreases from $5.4 \times$ $10^{-18} \mathrm{~m}^{2}$ at $3.6 \mathrm{MPa}$ effective mean stress to $2.9 \times$ $10^{-19} \mathrm{~m}^{2}$ at $54.6 \mathrm{MPa}$, and porosity decreases from $46 \%$ at $3.6 \mathrm{MPa}$ to $29 \%$ at $64.6 \mathrm{MPa}$. Permeability of the underthrust sample (Section 20R-1) decreases from $4.0 \times 10^{-18} \mathrm{~m}^{2}$ at $3.6 \mathrm{MPa}$ to $3.2 \times 10^{-19} \mathrm{~m}^{2}$ at $86.6 \mathrm{MPa}$, and porosity decreases from $48 \%$ to $36 \%$ over this stress range (see TESTDATA in "Supplementary material"). Estimated in situ porosities ( $\phi_{\text {in }}$ situ), defined as the porosity corresponding to the overburden assuming hydrostatic pore pressure, are $45 \%$ at a $\sigma_{\mathrm{vh}}{ }^{\prime}$ of $5.5 \mathrm{MPa}\left(\sigma_{\mathrm{m}}{ }^{\prime}=4.04 \mathrm{MPa}\right)$ and $47 \%$ at
7.3 $\mathrm{MPa}\left(\sigma_{\mathrm{m}}{ }^{\prime}=5.36 \mathrm{MPa}\right)$ for the prism and underthrust samples, respectively. These values are consistent with shipboard porosity measurements (Fig. F11) (Expedition 343/343T Scientists, 2013). Estimated values of in situ permeability $\left(k_{\text {in situ }}\right)$ for the prism and underthrust samples are $4.9 \times 10^{-18}$ and $3.6 \times 10^{-18} \mathrm{~m}^{2}$, respectively, and correspond to an in situ hydraulic conductivity of $3.1 \times 10^{-11}$ and $2.3 \times$ $10^{-11} \mathrm{~m} / \mathrm{s}$, respectively. In situ permeability and hydraulic conductivity values are also in good agreement with those estimated from CRS tests (Fig. F15; Table T4).

\section{Acknowledgments}

This research used samples that were obtained during the Integrated Ocean Drilling Program (IODP) and selected and stored through the efforts of shipboard scientists during Expedition 343 as part of JFAST. We thank Julia Reece and Frederick Chester for helpful comments that have improved the presentation and clarity of this report.

\section{References}

ASTM International, 2006. Standard test method for onedimensional consolidation properties of saturated cohesive soils using controlled-strain loading (Standard D4186-06). In Annual Book of ASTM Standards (Vol. 04.08): Soil and Rock (I): West Conshohocken, PA (Am. Soc. Testing Mater.) http://www.astm.org/DATABASE.CART/HISTORICAL/D4186-06.htm

Becker, D.E., Crooks, J.H.A., Been, K., and Jeffries, M.G., 1987. Work as a criterion for determining in situ and yield stresses in clays. Can. Geotech. J., 24(4):549-564. doi:10.1139/t87-070

Blum, P., 1997. Physical properties handbook: a guide to the shipboard measurement of physical properties of deep-sea cores. ODP Tech. Note, 26. doi:10.2973/ odp.tn.26.1997

Casagrande, A., 1936. The determination of preconsolidation load and its practical significance. In Casagrande, A., Rutledge, P.C., and Watson, J.D. (Eds.), Proc. 1st Int. Conf. Soil Mech. Found. Eng. Am. Soc. Civ. Eng., 3:60-64.

Dugan, B., and Daigle, H., 2011. Data report: permeability, compressibility, stress state, and grain size of shallow sediments from Sites C0004, C0006, C0007, and C0008 of the Nankai accretionary complex. In Kinoshita, M., Tobin, H., Ashi, J., Kimura, G., Lallemant, S., Screaton, E.J., Curewitz, D., Masago, H., Moe, K.T., and the Expedition 314/315/316 Scientists, Proc. IODP, 314/315/316: Tokyo (Integrated Ocean Drilling Program Management International, Inc.). doi:10.2204/ iodp.proc.314315316.208.2011 
Expedition 343/343T Scientists, 2013. Expedition 343/ 343T summary. In Chester, F.M., Mori, J., Eguchi, N., Toczko, S., and the Expedition 343/343T Scientists, Proc. IODP, 343/343T: Tokyo (Integrated Ocean Drilling Program Management International, Inc.). doi:10.2204/ iodp.proc.343343T.101.2013

Fujiwara, T., Kodaira, S., No, T., Kaiho, Y., Takahashi, N., and Kaneda, Y., 2011. The 2011 Tohoku-Oki earthquake: displacement reaching the trench axis. Science, 334(6060):1240. doi:10.1126/science.1211554

Germaine, J.T., and Germaine, A.V., 2009. Geotechnical Laboratory Measurements for Engineers: Hoboken, NJ (Wiley). doi:10.1002/9780470548790

Guo, J., Likos, W.J., Underwood, M.B., Skarbek, R.M., Adamson, N., and Saffer, D., 2011. Data report: consolidation characteristics of sediments from Sites C0002, C0006, and C0007, IODP Expeditions 315 and 316, NanTroSEIZE Stage 1. In Kinoshita, M., Tobin, H., Ashi, J., Kimura, G., Lallemant, S., Screaton, E.J., Curewitz, D., Masago, H., Moe, K.T., and the Expedition 314/315/316 Scientists, Proc. IODP, 314/315/316: Washington, DC (Integrated Ocean Drilling Program Management International, Inc.). doi:10.2204/ iodp.proc.314315316.213.2011

Holtz, R.D., and Kovacs, W.D., 1981. An Introduction to Geotechnical Engineering: Englewood Cliffs, NJ (PrenticeHall).
Ito, Y., Tsuji, T., Osada, Y., Kido, M., Inazu, D., Hayashi, Y., Tsushima, H., Hino, R., and Fujimoto, H., 2011. Frontal wedge deformation near the source region of the 2011 Tohoku-Oki earthquake. Geophys. Res. Lett., 38(7):L00G05. doi:10.1029/2011GL048355

Karig, D.E., 1990. Experimental and observational constraints on the mechanical behaviour in the toes of accretionary prisms. In Knipe, R.J., and Rutter, E.H. (Eds.), Deformation Mechanisms, Rheology and Tectonics. Geol. Soc. Spec. Publ., 54:383-398. doi:10.1144/ GSL.SP.1990.054.01.35

Long, H., Flemings, P.B., Germaine, J.T., Saffer, D.M., and Dugan, B., 2008. Data report: consolidation characteristics of sediments from IODP Expedition 308, Ursa Basin, Gulf of Mexico. In Flemings, P.B., Behrmann, J.H., John, C.M., and the Expedition 308 Scientists, Proc. IODP, 308: College Station, TX (Integrated Ocean Drilling Program Management International, Inc.). doi:10.2204/ iodp.proc.308.204.2008

Initial receipt: 18 November 2013

Acceptance: 12 November 2014

Publication: 3 February 2015

MS 343343T-201 
Figure F1. A. Location map, showing Site C0019 (red star) and previously drilled DSDP and ODP sites (green circles) (Expedition 343/343T Scientists, 2013). White arrow $=$ Pacific plate convergence vector, black star $=$ Tohoku-oki epicenter. B. Close up of Site C0019.

\section{A}

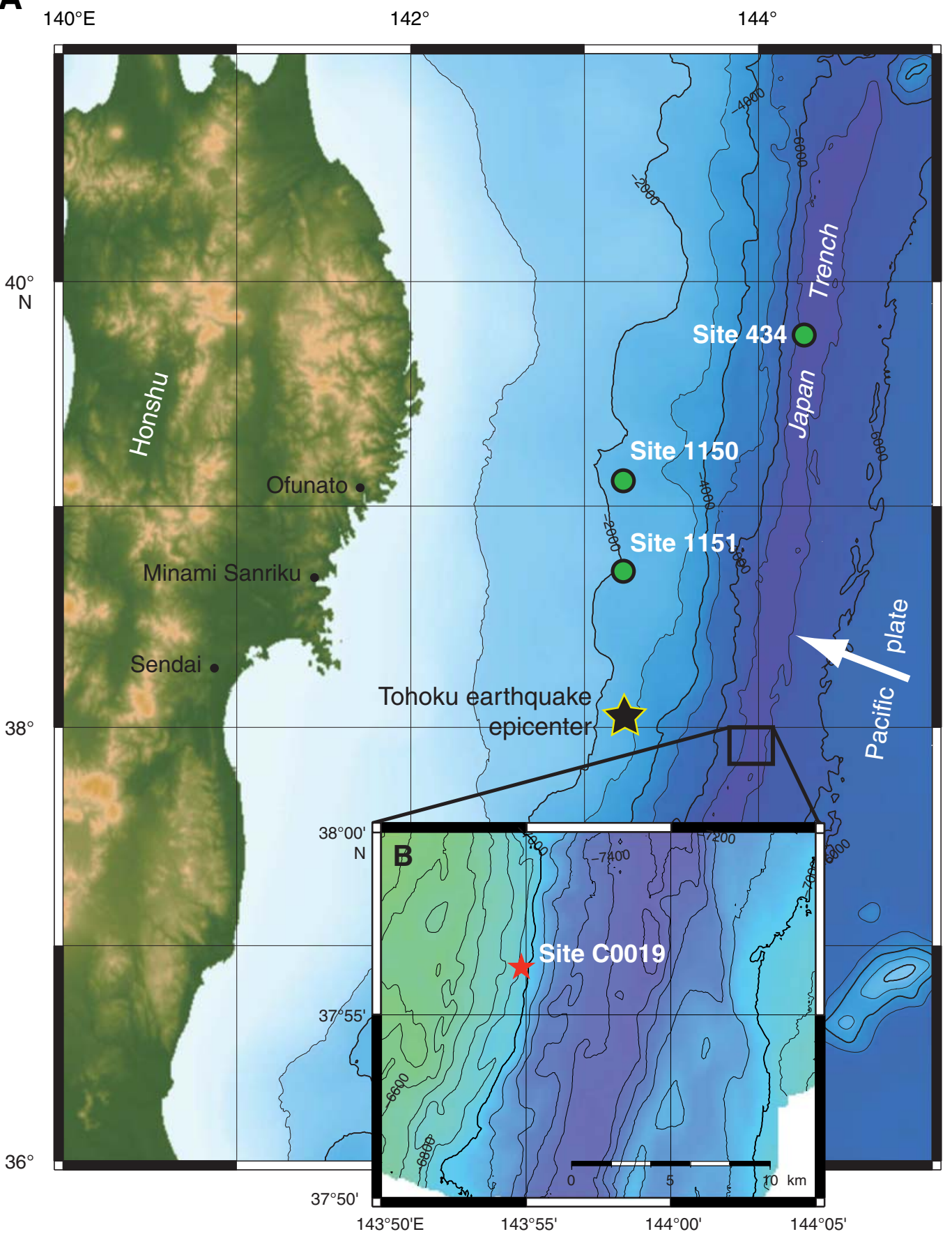


Figure F2. Schematic diagram of the high-stress uniaxial apparatus at The Pennsylvania State University. The top chamber is drained and open to the syringe pump at a controlled back pressure, whereas the lower chamber is connected to a pore pressure transducer but otherwise undrained. Axial displacement is measured using a linear variable differential transformer (LVDT) and axial load is measured with a load cell.

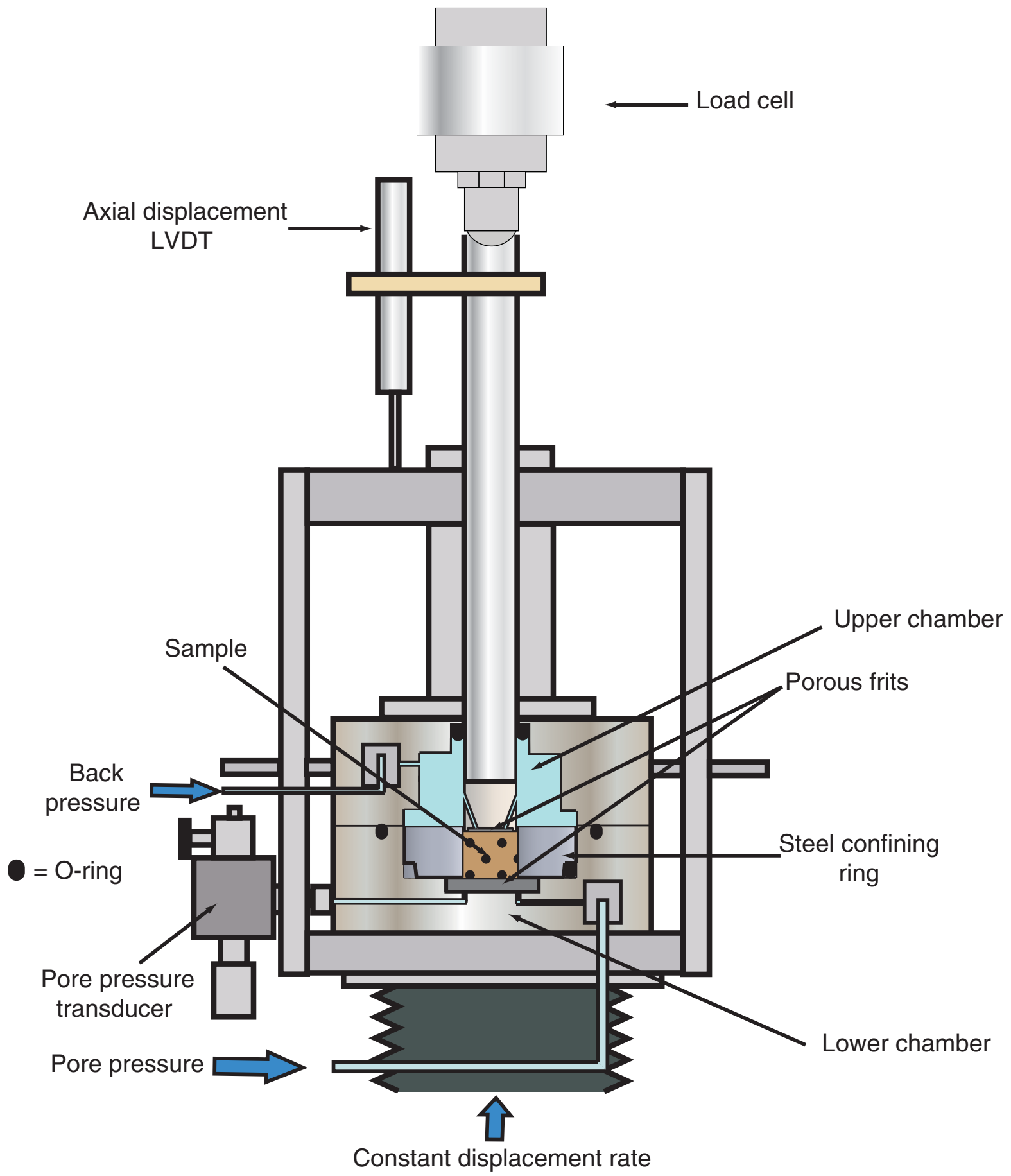


Figure F3. Schematic diagram of the triaxial apparatus. Confining pressure and axial stress are controlled by a high-pressure syringe pump using silicone oil as the confining medium. In our tests, the axial stress and confining pressure are equal, to achieve an isostatic loading path. Upstream and downstream pore pressures are controlled by two syringe pumps, to allow flow-through permeability measurements. Sample length is measured via an external linear variable differential transformer (LVDT), and length changes are corrected for the system compliance using an empirically defined calibration.

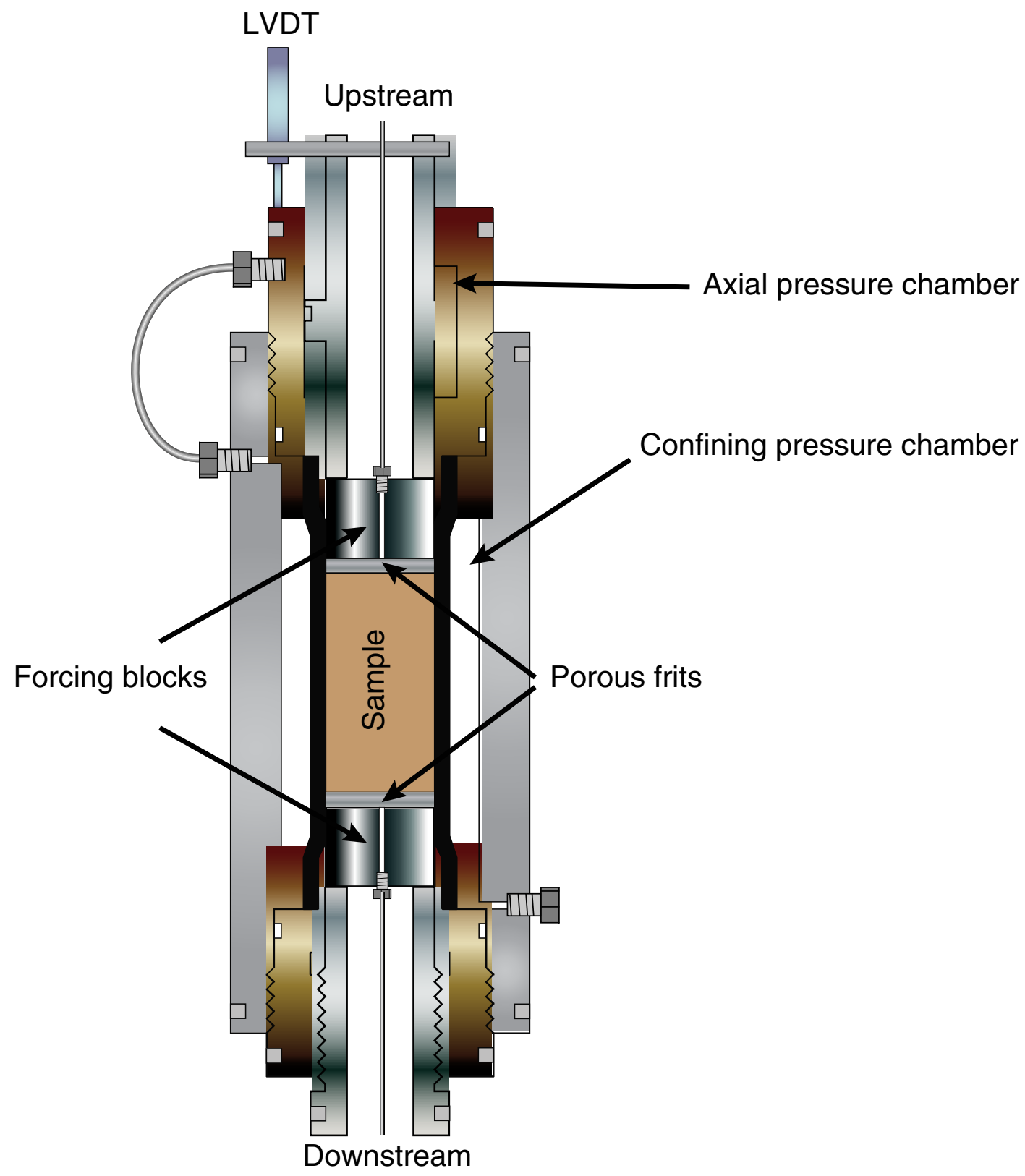


Figure F4. Example of the Casagrande and SED method showing the determination of preconsolidation pressure $\left(P_{\mathrm{c}}{ }^{\prime}\right)$. A. $P_{\mathrm{c}}{ }^{\prime}$ for prism sample (Test U291 on Section 343-C0019E-5R-1) using the Casagrande method. In this method, the point of maximum curvature is determined. At this point, a line of constant void ratio (Segment B) and a line tangent to the same point (Segment A) is drawn. The intersection of their bisector (Segment C) and the line parallel to the virgin compression line defines $P_{c}^{\prime}$. B. $P_{c}^{\prime}$ for prism sample (Test U291 on Section 5R-1) using the SED method. In the SED method, a line is fit to the early portion of the data and the virgin compression line. $P_{\mathrm{c}}^{\prime}$ is defined by their intersection. C. Casagrande method for underthrust sample (Test U293 on Section 20R-1). D. SED method for underthrust sample (Test U293 on Section 20R-1).

A

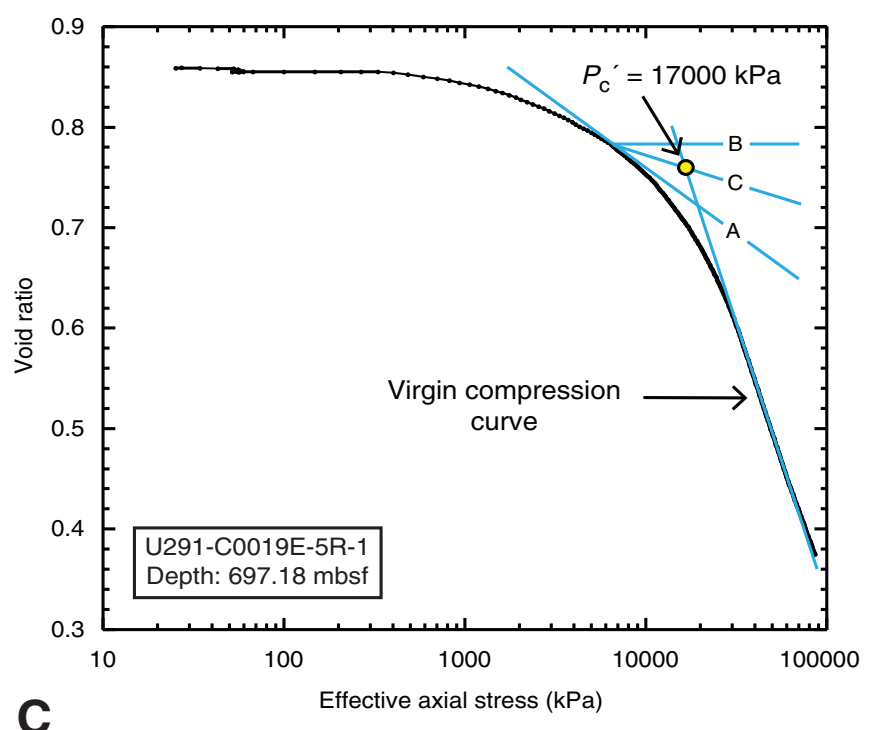

C

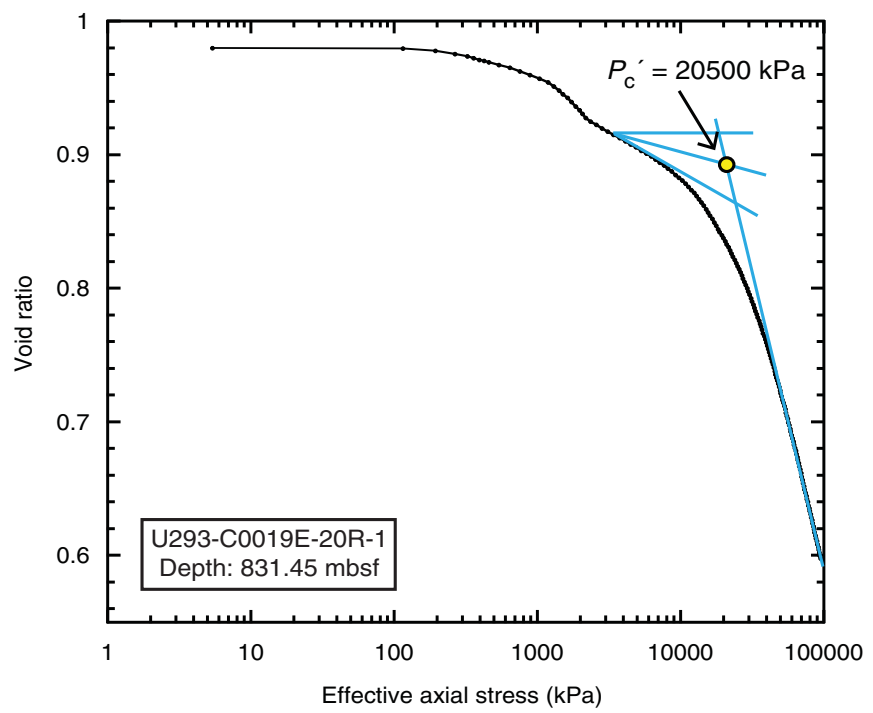

B

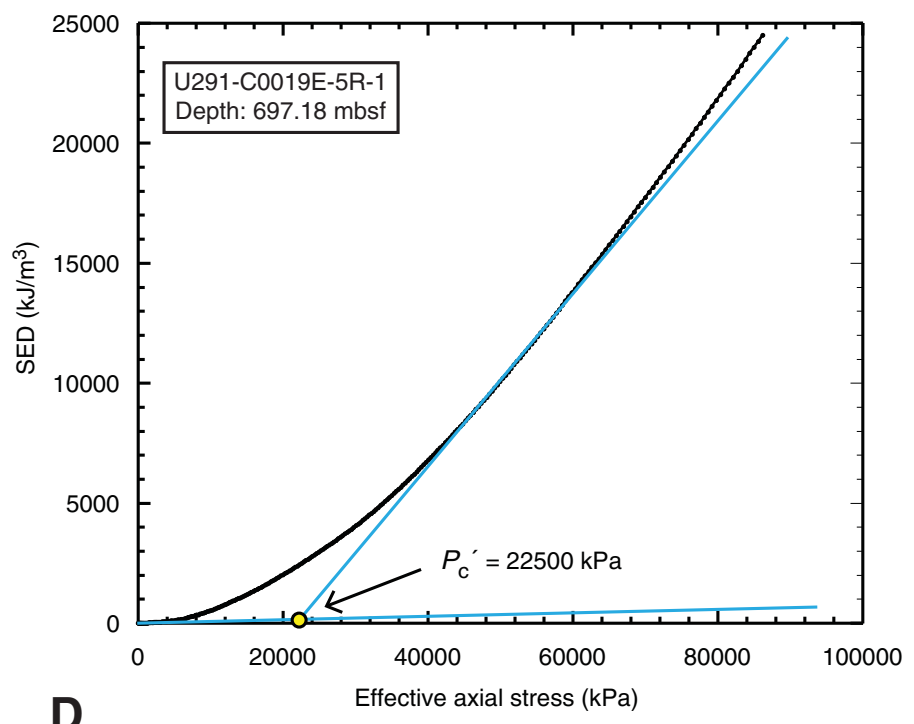

D

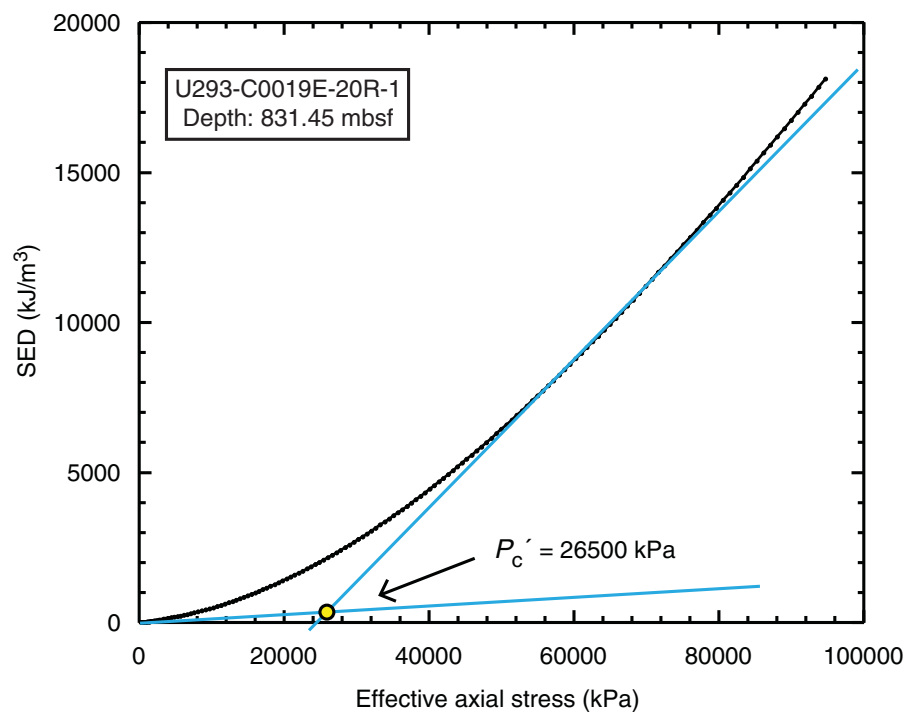


Figure F5. Time series data for Test U291 on prism sample (Section 343-C0019E-5R-1). A. Effective axial stress (black) and excess basal pore pressure (blue). The excess basal pore pressure remained $<12 \%$ of the effective axial stress (e.g., ASTM International, 2006). B. Excess basal pore pressure.

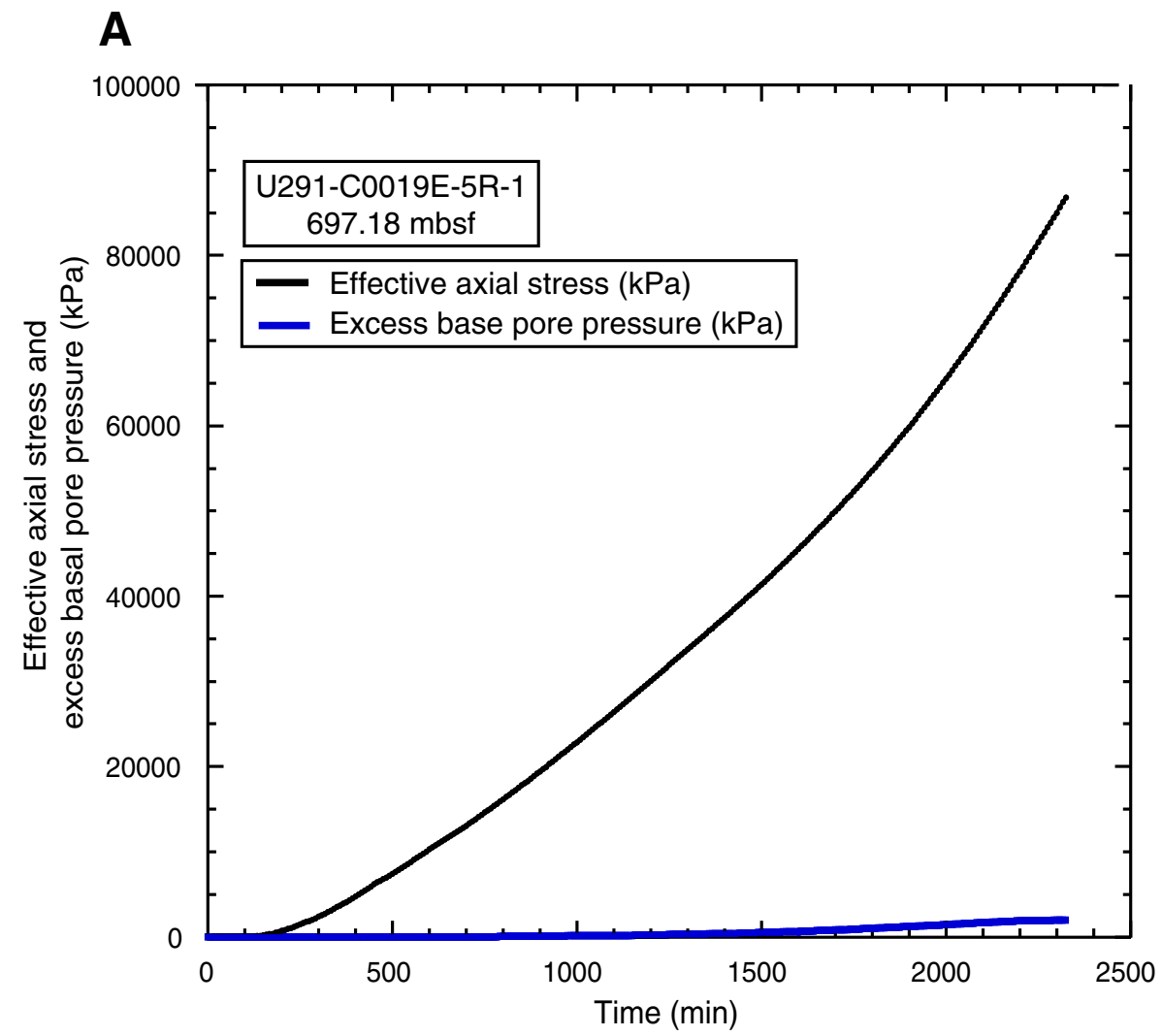

B

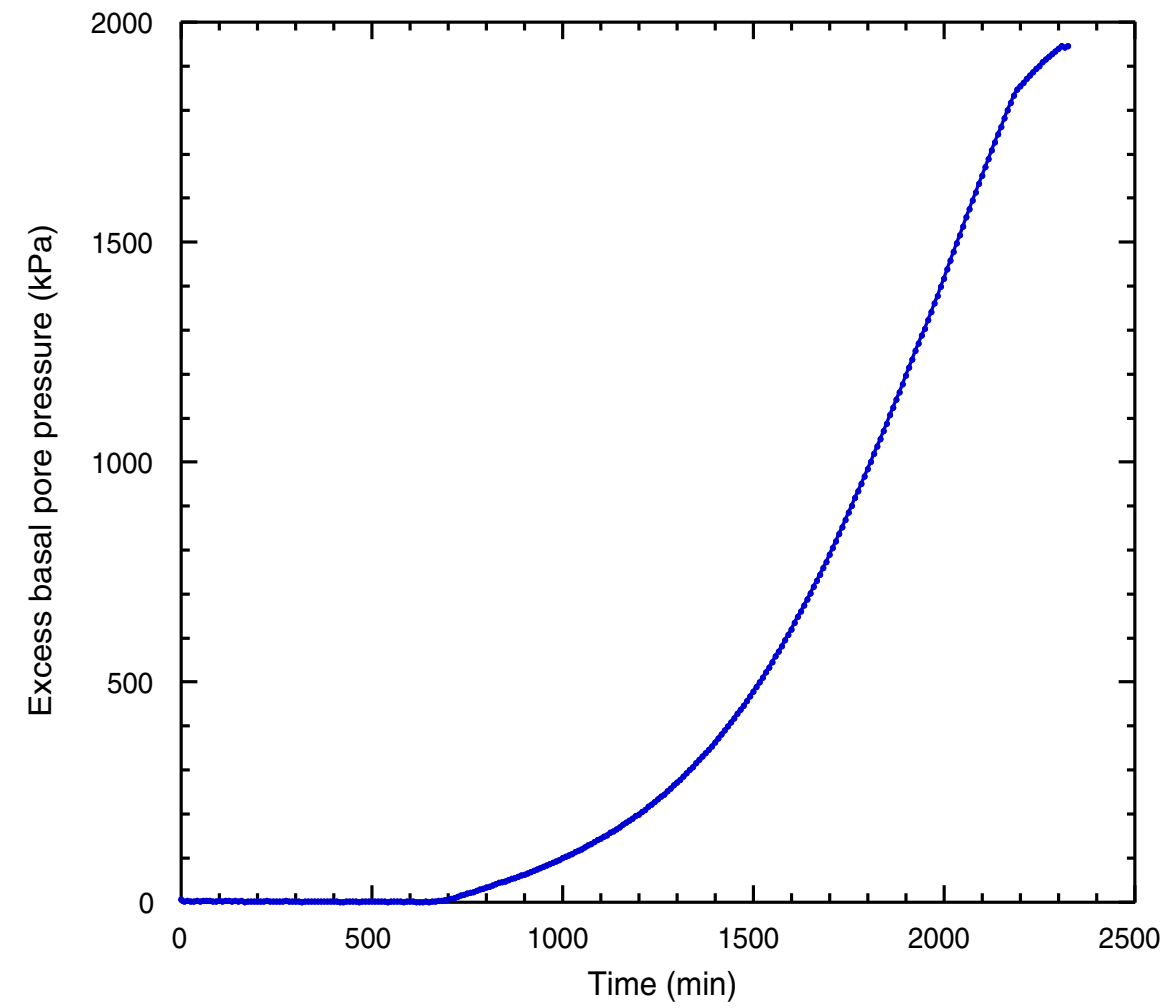


Figure F6. Experimental results for CRS Test U291 on prism sample (Section 343-C0019E-5R-1). SED = strain energy density.
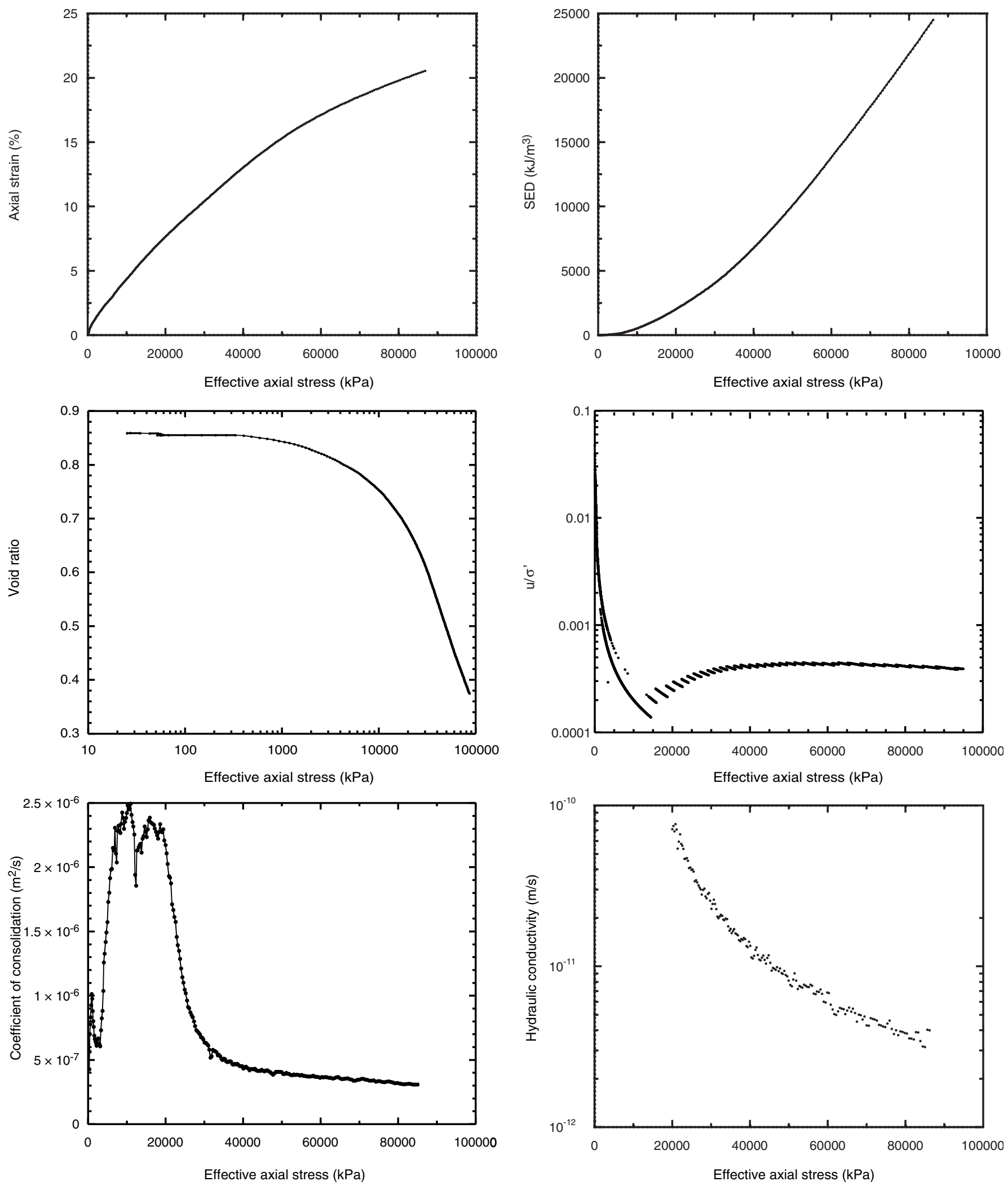
Figure F7. Permeability, porosity, and conductivity results for CRS Test U291 on prism sample (Section 343C0019E-5R-1).
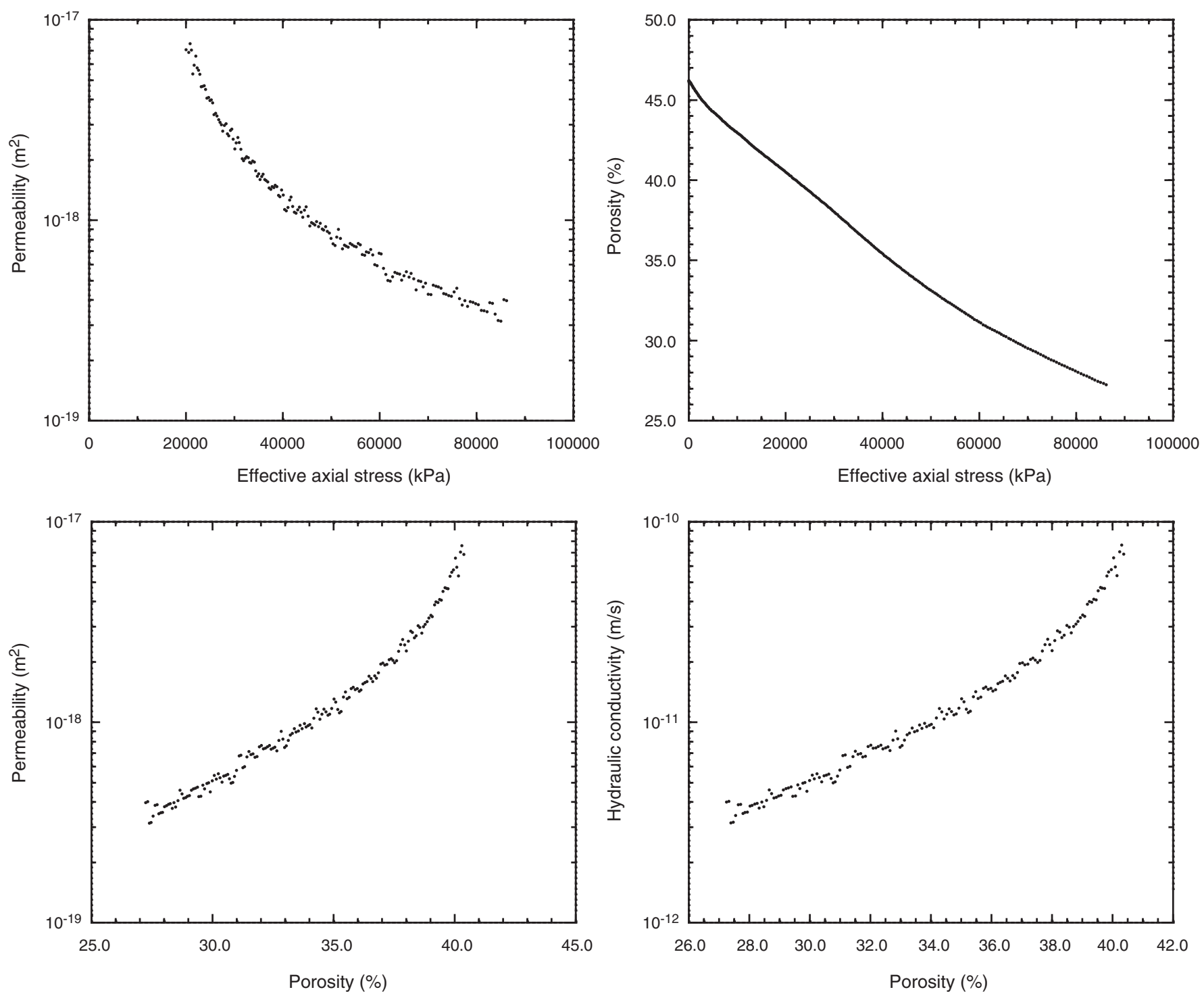
Figure F8. Time series data for Test U293 on underthrust sample (Section 343-C0019E-20R-1). A. Effective axial stress and excess basal pore pressure. Excess basal pore pressure remained $<12 \%$ of effective axial stress (e.g., ASTM International, 2006). B. Excess basal pore pressure did not build sufficient pressure to calculate the hydraulic conductivity and permeability.
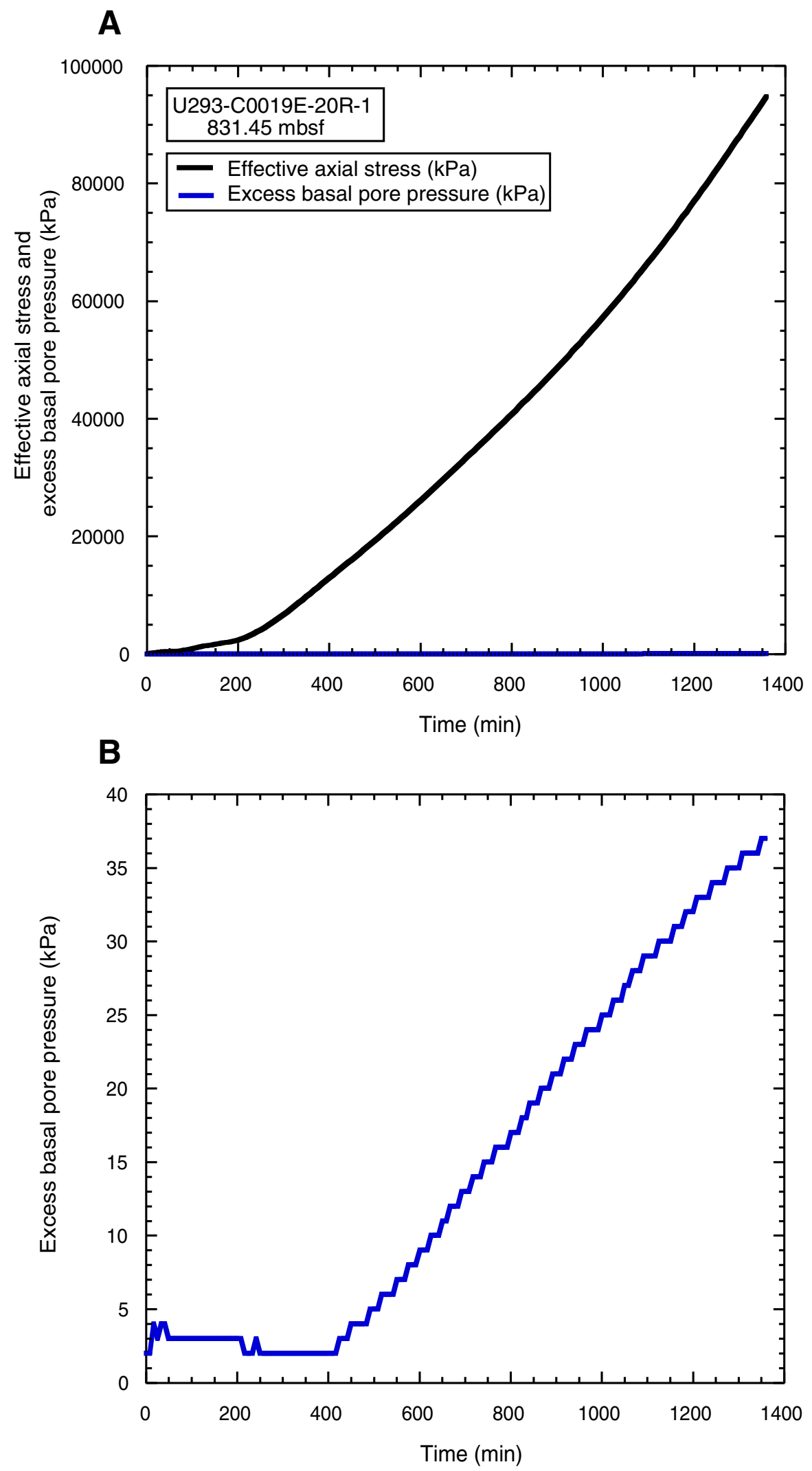
Figure F9. Experimental results for CRS Test U293 on underthrust sample (Section 343-C0019E-20R-1). SED = strain energy density.
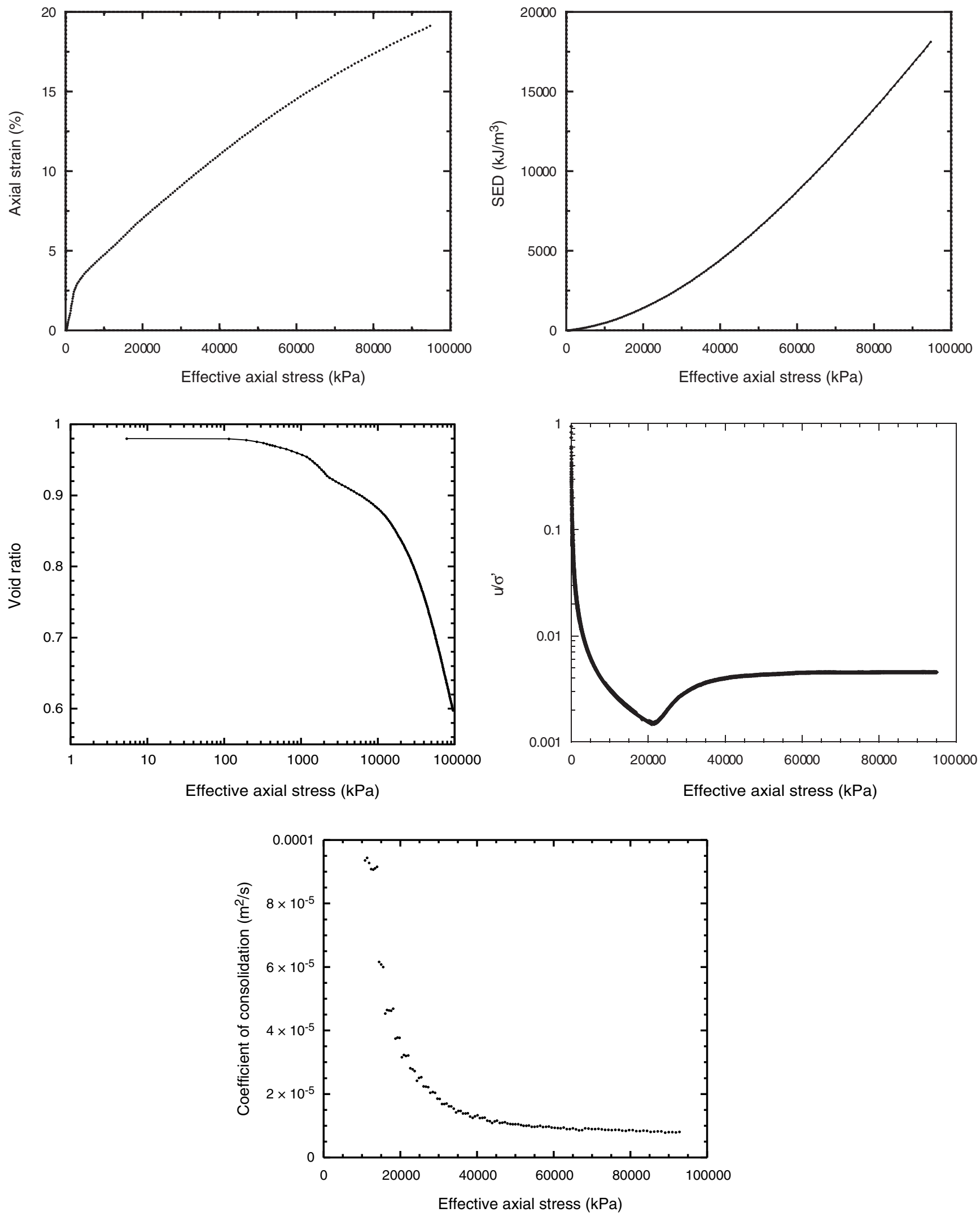
Figure F10. Porosity results for CRS Test U293 on underthrust sample (Section 343-C0019E-20R-1).

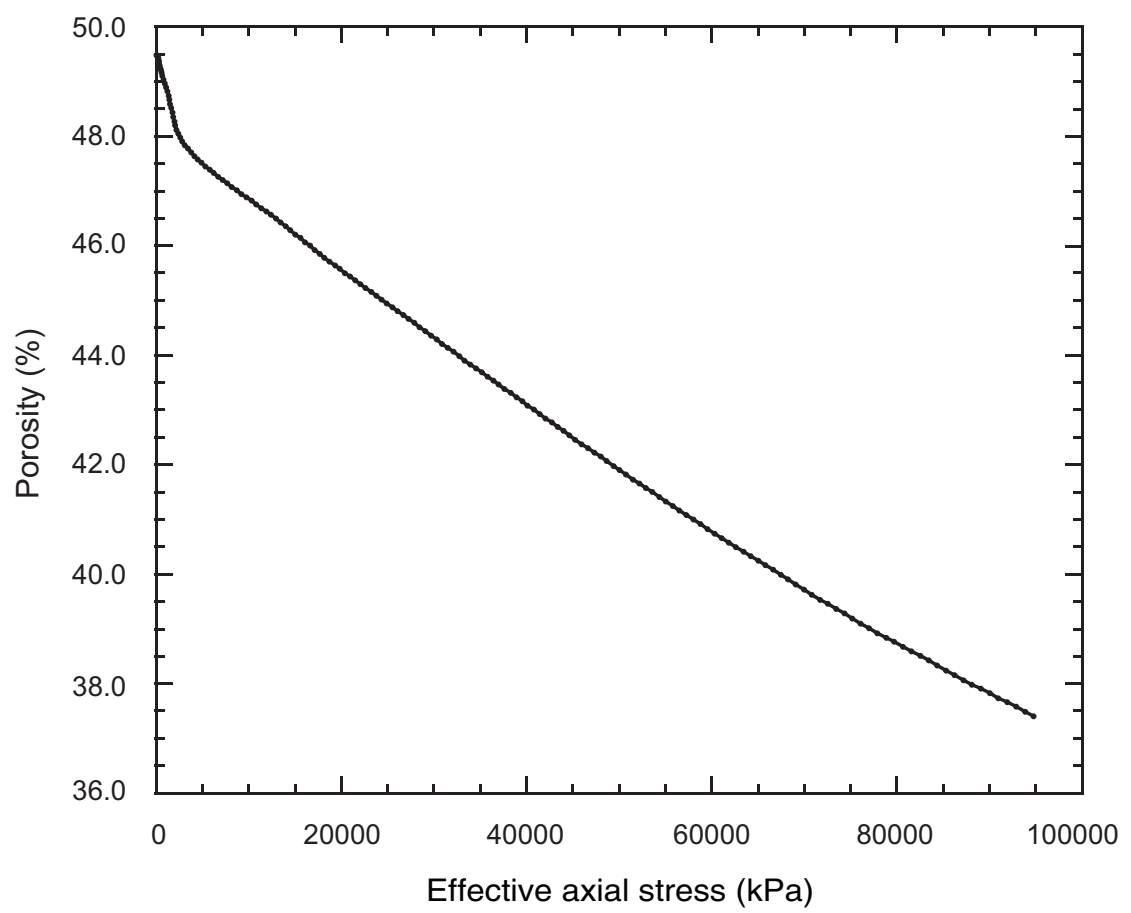


Figure F11. In situ porosity estimates for prism sample (Section 343-C0019E-5R-1) from Tests U291 and T70303 and underthrust sample (Section 20R-1) from Tests U293 and T100-292 compared with porosity moisture and density (MAD) measurements conducted shipboard as part of Expedition 343 in Hole C0019E.

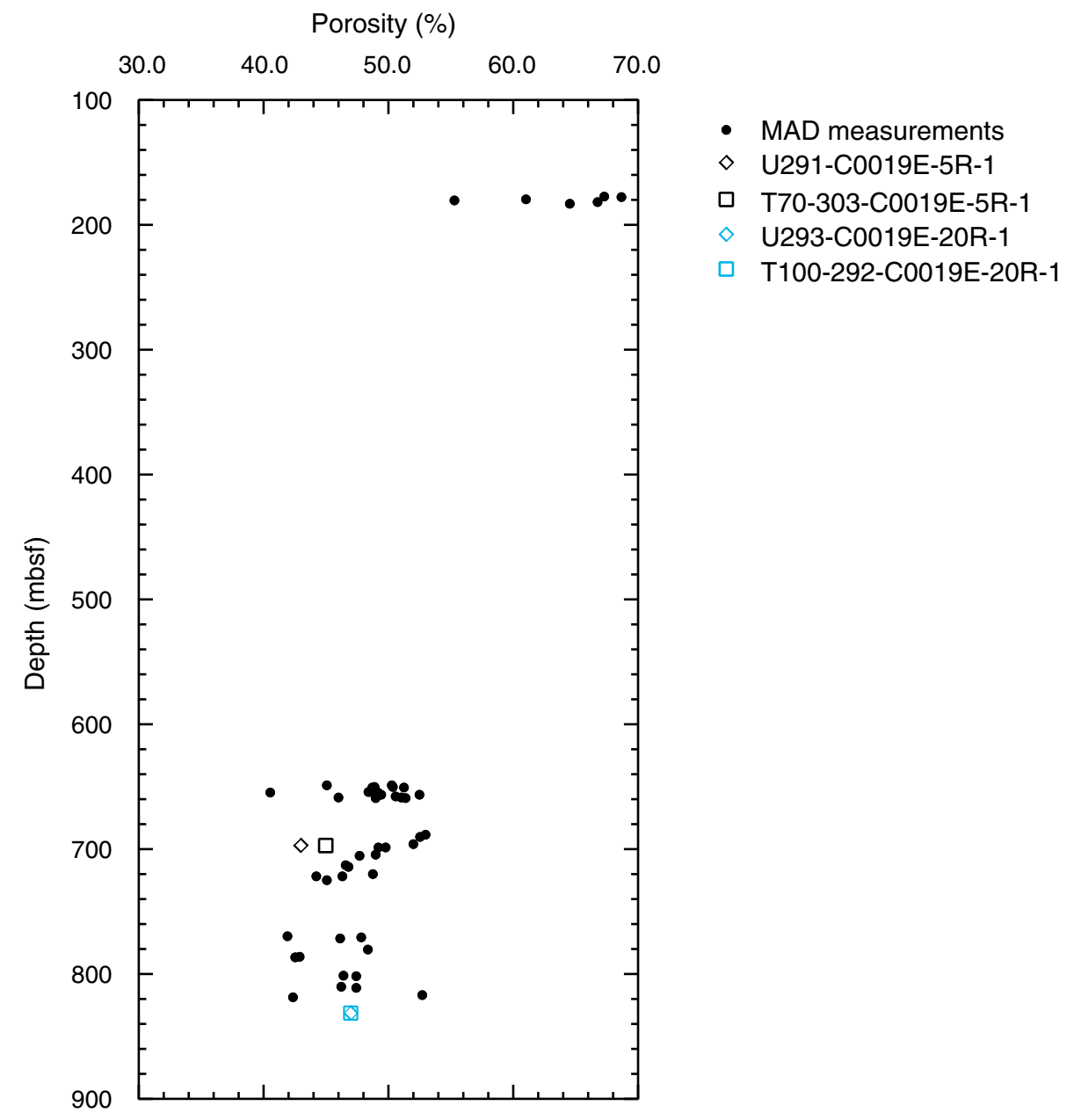


Figure F12. Permeability test example on prism sample (Section 343-C0019-5R-1). Upstream and downstream flow rates have equilibrated, with equal magnitude and opposite sign.

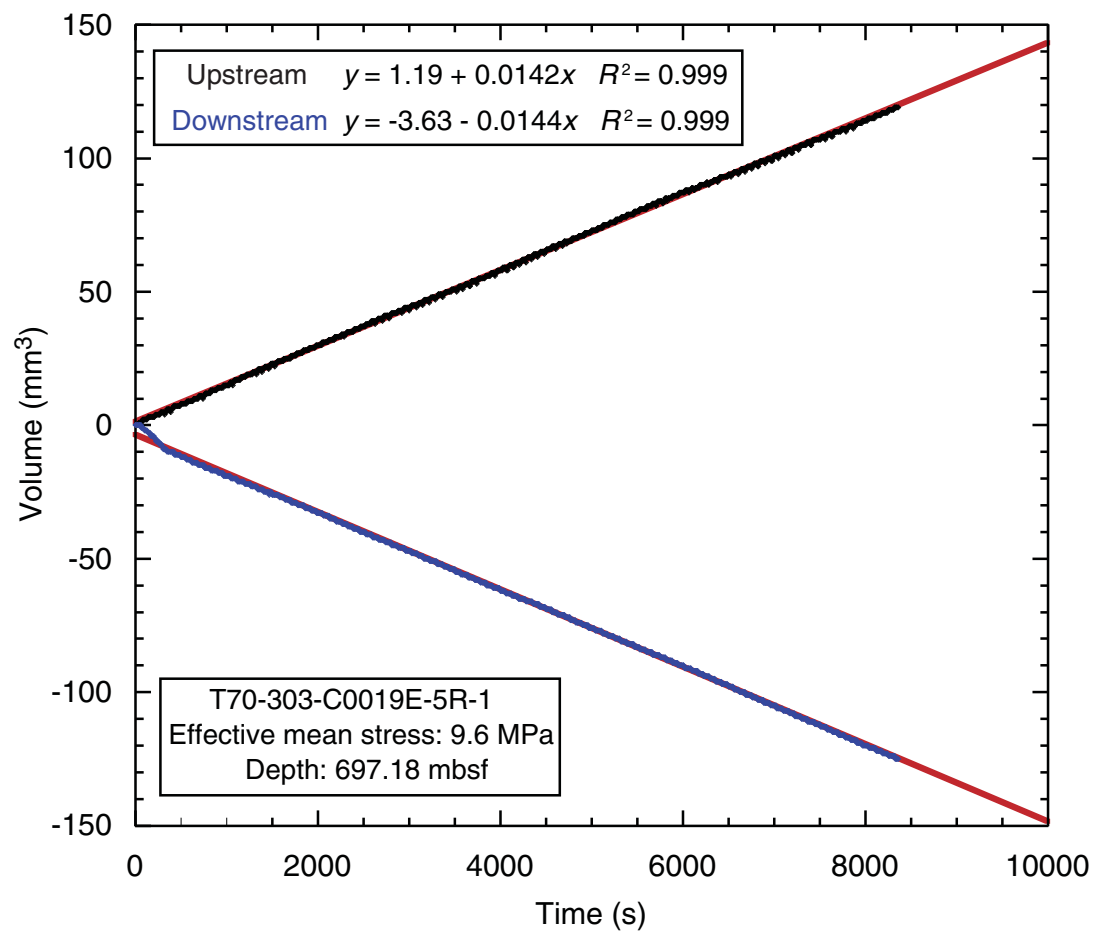


Figure F13. Experimental results for triaxial Test T70-303 on prism sample (Section 343-C0019E-5R-1).
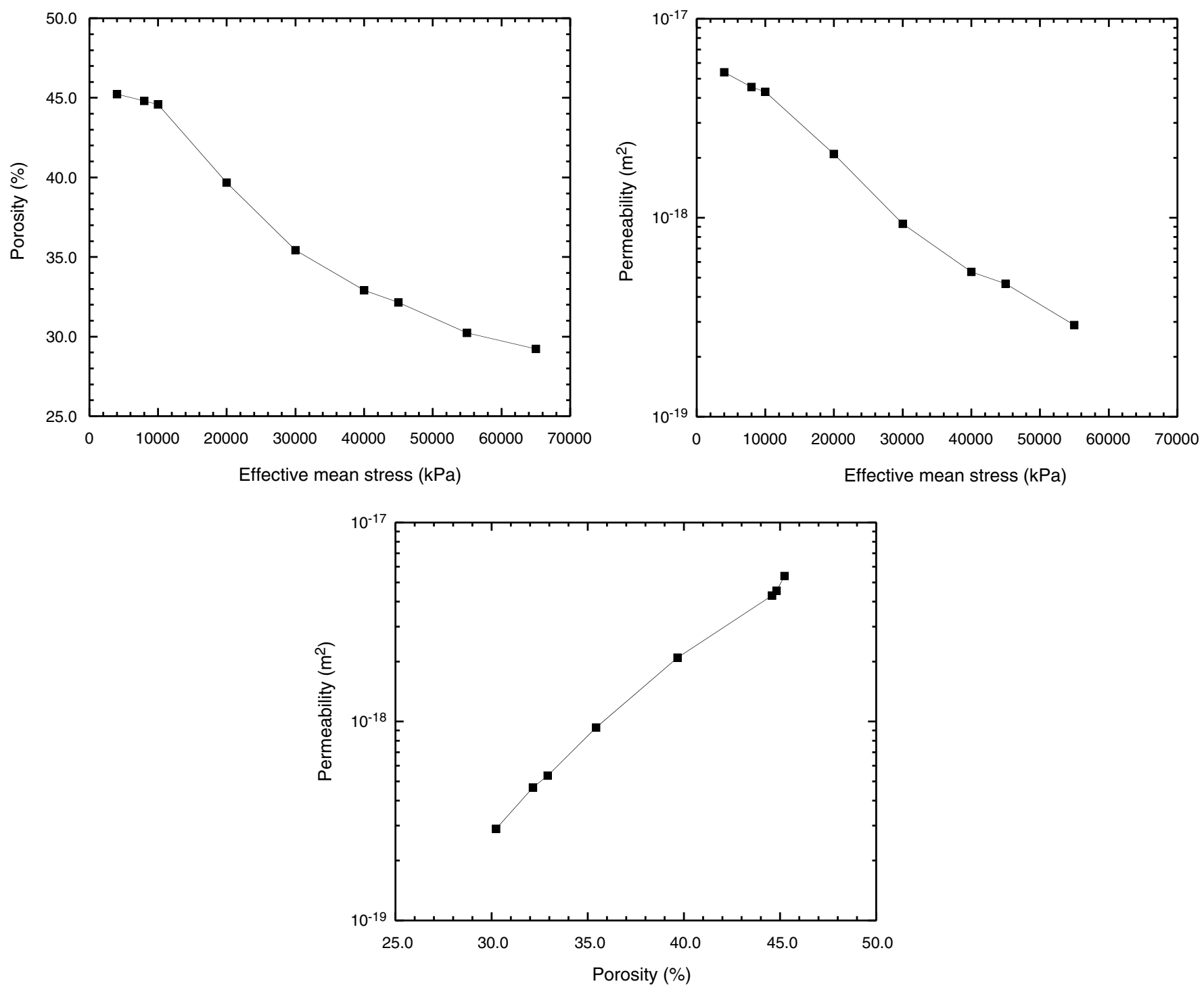
Figure F14. Experimental results for triaxial Test T100-292 on underthrust sample (Section 343-C0019E-20R-1).
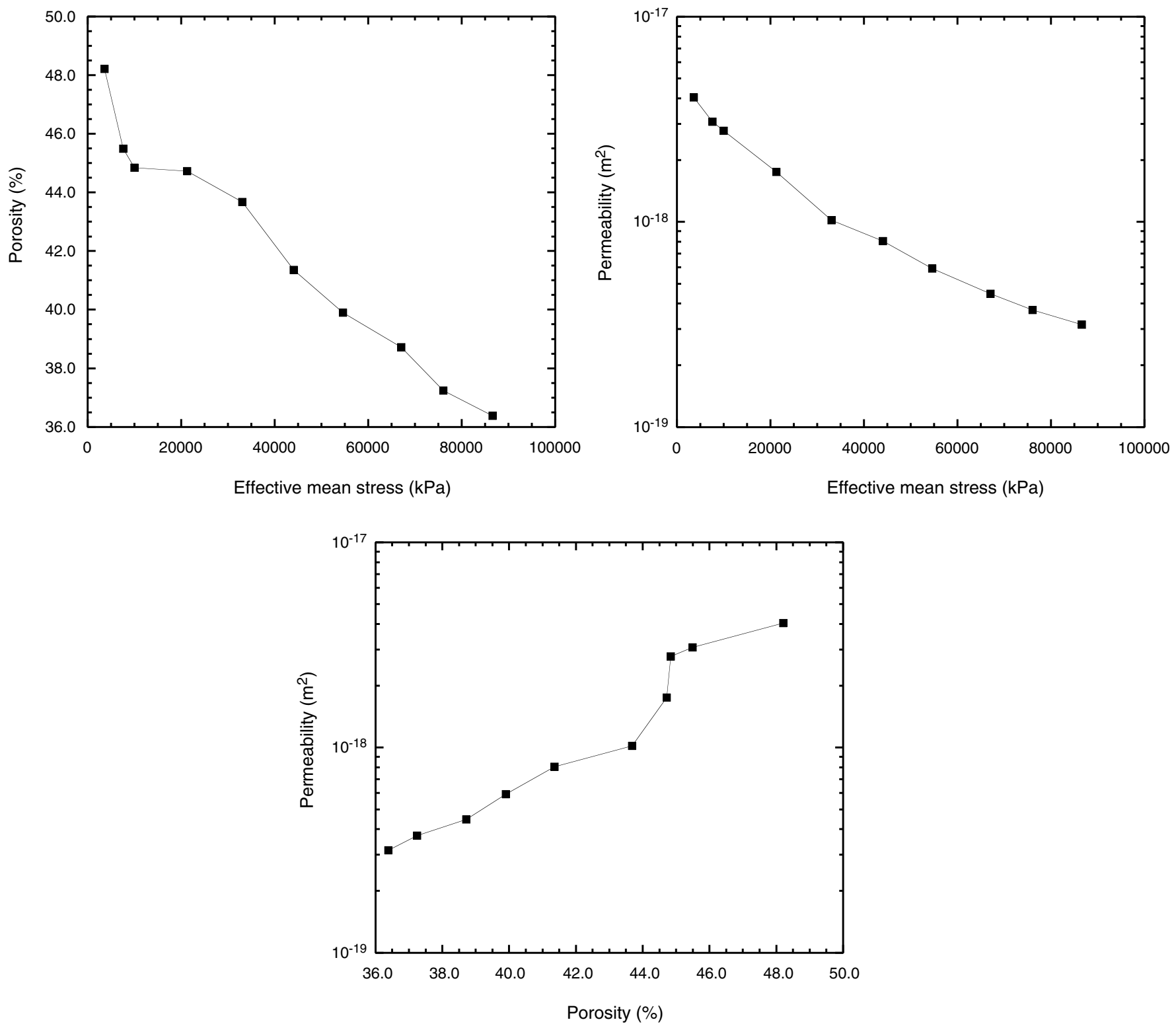
Figure F15. Summary of experimental results for prism sample (Section 343-C0019E-5R-1) from CRS Test U291 and triaxial Test T70-303 and underthrust sample (Section 20R-1) from CRS Test U293 and triaxial Test T100292). Estimated in situ permeability and porosity values for both samples are also shown.
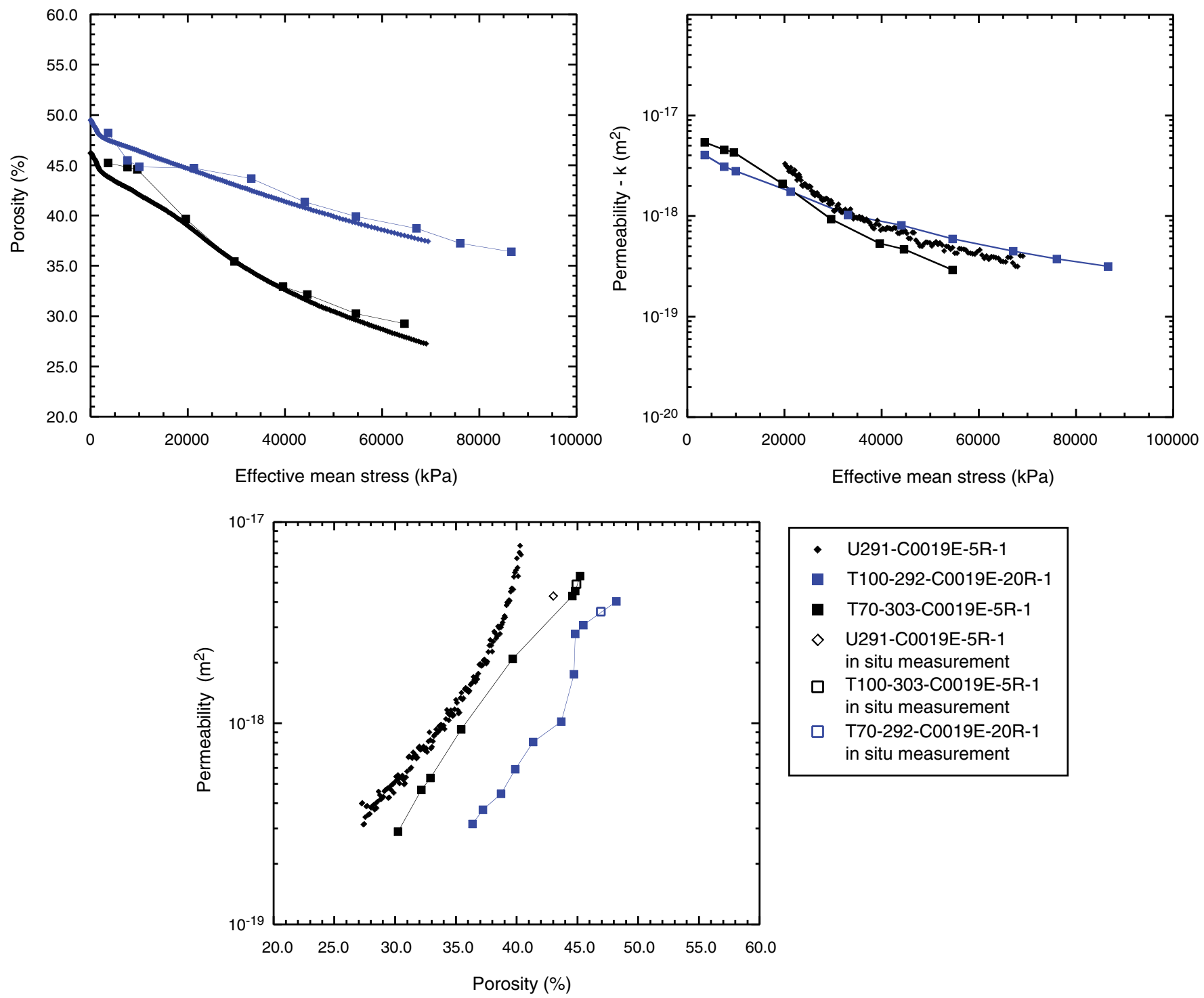

- U291-C0019E-5R-1

- T100-292-C0019E-20R-1

- T70-303-C0019E-5R-1

$\diamond \quad \mathrm{U} 291-\mathrm{C} 0019 \mathrm{E}-5 \mathrm{R}-1$ in situ measurement

T100-303-C0019E-5R-1 in situ measurement

ㄱ T70-292-C0019E-20R-1 in situ measurement 
Table T1. Nomenclature.

\begin{tabular}{|c|c|c|c|}
\hline Variable & Definition & Dimension & Unit \\
\hline$A$ & Cross-sectional area & $L^{2}$ & $\mathrm{~m}^{2}$ \\
\hline$c_{c}$ & Compression index & - & - \\
\hline$C_{v}$ & Coefficient of consolidation & $\mathrm{L}^{2} / \mathrm{T}$ & $\mathrm{m}^{2} / \mathrm{s}$ \\
\hline e & Void ratio & Dimensionless & - \\
\hline$\Delta e$ & Change in void ratio & Dimensionless & - \\
\hline g & Gravitational acceleration & $\mathrm{L} / \mathrm{T}^{2}$ & $\mathrm{~m} / \mathrm{s}^{2}$ \\
\hline$H_{\mathrm{n}}$ & Current specimen height & L & $\mathrm{mm}$ \\
\hline$H_{\mathrm{s}}$ & Height of the solids & L & $\mathrm{mm}$ \\
\hline$H_{0}$ & Initial height & $\mathrm{L}$ & $\mathrm{mm}$ \\
\hline K & Hydraulic conductivity & $\mathrm{L} / \mathrm{T}$ & $\mathrm{m} / \mathrm{s}$ \\
\hline$K_{\text {in situ }}$ & In situ hydraulic conductivity & $\mathrm{L} / \mathrm{T}$ & $\mathrm{m} / \mathrm{s}$ \\
\hline$K_{0}$ & Coefficient of lateral stress at rest & Dimensionless & - \\
\hline$k$ & Permeability & $L^{2}$ & $\mathrm{~m}^{2}$ \\
\hline$k_{\text {in situ }}$ & In situ permeability & $\mathrm{L}^{2}$ & $\mathrm{~m}^{2}$ \\
\hline$m_{\mathrm{v}}$ & Coefficient of volume compressibility & $\mathrm{LT}^{2} / \mathrm{M}$ & $1 / \mathrm{kPa}$ \\
\hline OCR & Overconsolidation ratio & Dimensionless & - \\
\hline$P_{c}^{\prime}$ & Preconsolidation pressure & $\mathrm{M} / \mathrm{LT}^{2}$ & $\mathrm{kPa}$ \\
\hline$P_{\mathrm{f}}$ & (Basal) pore fluid pressure & $\mathrm{M} / \mathrm{LT}^{2}$ & $\mathrm{kPa}$ \\
\hline$P_{\text {p_down }}$ & Downstream pore pressure & $\mathrm{M} / \mathrm{LT}^{2}$ & $\mathrm{kPa}$ \\
\hline$P_{\text {p_up }}^{P}$ & Upstream pore pressure & $\mathrm{M} / \mathrm{LT}^{2}$ & $\mathrm{kPa}$ \\
\hline$Q^{2-a p}$ & Flow rate & $\mathrm{M}^{3} / \mathrm{T}$ & $\mathrm{m}^{3} / \mathrm{s}$ \\
\hline$\Delta u$ & Excess basal pore pressure & $\mathrm{M} / \mathrm{LT}^{2}$ & $\mathrm{kPa}$ \\
\hline$\varepsilon$ & Vertical strain & Dimensionless & - \\
\hline$\Delta e$ & Change in vertical strain & Dimensionless & - \\
\hline$\dot{\varepsilon}$ & Strain rate & $1 / \mathrm{T}$ & $1 / \mathrm{h}$ \\
\hline$\phi$ & Porosity & Dimensionless & - \\
\hline$\phi_{\text {in situ }}$ & In situ porosity & Dimensionless & - \\
\hline$\mu$ & Fluid viscosity & $\mathrm{M} / \mathrm{LT}$ & $\mathrm{Pa} \cdot \mathrm{s}$ \\
\hline$\rho_{\mathrm{w}}$ & Density of seawater & $\mathrm{M} / \mathrm{L}^{3}$ & $\mathrm{~kg} / \mathrm{m}^{3}$ \\
\hline$\sigma_{\mathrm{A}}$ & Total axial stress & $\mathrm{M} / \mathrm{LT}^{2}$ & $\mathrm{kPa}$ \\
\hline$\sigma_{A}^{\prime}$ & Effective axial stress & $\mathrm{M} / \mathrm{LT}^{2}$ & $\mathrm{kPa}$ \\
\hline$\Delta \sigma_{A}^{\prime}$ & Change in effective axial stress & $\mathrm{M} / \mathrm{LT}^{2}$ & $\mathrm{kPa}$ \\
\hline$\sigma_{\mathrm{m}}^{\prime}$ & Effective mean stress & $\mathrm{M} / \mathrm{LT}^{2}$ & $\mathrm{kPa}$ \\
\hline$\sigma_{H^{\prime}}^{\prime \prime}$ & Effective horizontal stress & $\mathrm{M} / \mathrm{LT}^{2}$ & $\mathrm{kPa}$ \\
\hline$\sigma_{\mathrm{vh}}^{\prime}$ & Effective vertical stress at hydrostatic & $\mathrm{M} / \mathrm{LT}^{2}$ & $\mathrm{kPa}$ \\
\hline$\sigma_{1}^{\prime}, \sigma_{2}^{\prime}, \sigma_{3}^{\prime}$ & effective principal stresses & $\mathrm{M} / \mathrm{LT}^{2}$ & $\mathrm{kPa}$ \\
\hline
\end{tabular}

$-=$ not applicable.

Table T2. Summary of cores used in constant rate of strain (CRS) and triaxial tests, Hole C0019E.

\begin{tabular}{|c|c|c|c|c|c|}
\hline Test & $\begin{array}{l}\text { Core, } \\
\text { section }\end{array}$ & $\begin{array}{l}\text { Depth } \\
\text { (mbsf) }\end{array}$ & Unit & Lithology & Test type \\
\hline & \multicolumn{5}{|c|}{ 343-C0019E- } \\
\hline U291 & $5 \mathrm{R}-1$ & 697.18 & III & Gray mudstone & CRS \\
\hline T70-303 & $5 R-1$ & 697.18 & III & Gray mudstone & Triaxial \\
\hline U293 & 20R-1 & 831.45 & V & Brown mudstone & CRS \\
\hline T100-292 & 20R-1 & 831.45 & V & Brown mudstone & Triaxial \\
\hline
\end{tabular}

Table T3. Consolidation properties, Hole C0019E.

\begin{tabular}{|c|c|c|c|c|c|c|c|c|c|c|c|c|}
\hline \multicolumn{3}{|c|}{ Test information } & \multicolumn{3}{|c|}{ Specimen information } & \multirow{2}{*}{$\begin{array}{c}\text { Test } \\
\text { conditions } \\
\begin{array}{c}\text { Strain rate } \\
(\% / \mathrm{h})\end{array}\end{array}$} & \multicolumn{6}{|c|}{ Consolidation properties } \\
\hline Test & $\begin{array}{c}\text { Core, } \\
\text { section }\end{array}$ & $\begin{array}{l}\text { Depth } \\
\text { (mbsf) }\end{array}$ & $\begin{array}{l}\text { Height } \\
(\mathrm{mm})\end{array}$ & $\begin{array}{l}\text { Diameter } \\
(\mathrm{mm})\end{array}$ & $\begin{array}{l}\text { Initial void } \\
\text { ratio }\end{array}$ & & $\mathrm{C}_{\mathrm{c}}$ & $C_{V}\left(\mathrm{~m}^{2} / \mathrm{s}\right)$ & $\begin{array}{c}P_{\mathrm{c}}^{\prime} \text { Casag } \\
(\mathrm{kPa})\end{array}$ & $\begin{array}{c}P_{c}^{\prime} \text { SED } \\
(\mathrm{kPa})\end{array}$ & $\begin{array}{l}\text { OCR } \\
\text { Casag }\end{array}$ & $\begin{array}{l}\text { OCR } \\
\text { SED }\end{array}$ \\
\hline \multicolumn{13}{|c|}{ 343-C0019E- } \\
\hline U291 & $5 \mathrm{R}-1$ & 697.18 & 15.7 & 25.4 & 0.85 & 0.57 & 0.70 & 4.20E-07 & 17,000 & 23,600 & 3.1 & 4.3 \\
\hline U293 & 20R-1 & 831.45 & 19.0 & 25.4 & 0.96 & 0.86 & 0.57 & $9.00 \mathrm{E}-06$ & 20,500 & 26,500 & 2.8 & 3.6 \\
\hline
\end{tabular}

Casag $=$ Casagrande, $\mathrm{SED}=$ strain energy density, $\mathrm{OCR}=$ overconsolidation ratio. 
Table T4. Estimated in situ properties, Hole C0019E.

\begin{tabular}{|c|c|c|c|c|c|c|}
\hline \multicolumn{3}{|c|}{ Test information } & \multicolumn{4}{|c|}{ In situ properties } \\
\hline Test & $\begin{array}{c}\text { Core, } \\
\text { section }\end{array}$ & $\begin{array}{l}\text { Depth } \\
\text { (mbsf) }\end{array}$ & $\begin{array}{c}\sigma_{\mathrm{vh}}^{\prime} \\
(\mathrm{kPa})\end{array}$ & $K_{\text {in situ }}(\mathrm{m} / \mathrm{s})$ & $k_{\text {in situ }}\left(\mathrm{m}^{2}\right)$ & $\begin{array}{c}\phi_{\text {in situ }} \\
(\%)\end{array}$ \\
\hline \multicolumn{7}{|c|}{ 343-C0019E- } \\
\hline U291 & $5 R-1$ & 697.18 & 5510 & $2.7 \times 10^{-11}$ & $4.3 \times 10^{-18}$ & 44 \\
\hline T70-303 & $5 R-1$ & 697.18 & 5510 & $3.1 \times 10^{-11}$ & $4.9 \times 10^{-18}$ & 45 \\
\hline U293 & $20 \mathrm{R}-1$ & 831.45 & 7310 & NA & NA & 47 \\
\hline T100-292 & $20 R-1$ & 831.45 & 7310 & $2.3 \times 10^{-11}$ & $3.6 \times 10^{-18}$ & 47 \\
\hline
\end{tabular}

